\title{
Different features of the cortical sensorimotor rhythms are uniquely linked to the severity of specific symptoms in Parkinson's disease
}

\section{Authors}

Mikkel C. Vinding* 1), Allison Eriksson 1)2), Cassia Man Ting Low 1)3), Josefine Waldthaler 4)5), Daniel Ferreira 6,7), Martin Ingvar 1), Per Svenningsson 4), Daniel Lundqvist 1).

\section{Affiliations}

1. NatMEG, Department of Clinical Neuroscience, Karolinska Institutet, Sweden.

2. Department of Women's and Children's Health, Uppsala University, Sweden.

3. Cognitive Neuroimaging Centre, Lee Kong Chien School of Medicine, Nanyang Technological University, Singapore.

4. Neuro Svenningsson, Department of Clinical Neuroscience, Karolinska Institutet, Sweden.

5. Department of Neurology, University Hospital Marburg, Marburg, Germany.

6. Division of Clinical Geriatrics, Center for Alzheimer's Research, Department of Neurobiology, Care Sciences, and Society, Karolinska Institutet, Stockholm, Sweden.

7. Department of Radiology, Mayo Clinic, Rochester, MN, USA. 
medRxiv preprint doi: https://doi.org/10.1101/2021.06.27.21259592; this version posted June 30, 2021. The copyright holder for this preprint (which was not certified by peer review) is the author/funder, who has granted medRxiv a license to display the preprint in perpetuity.

It is made available under a CC-BY 4.0 International license .

\section{Abstract}

Parkinson's disease (PD) is associated with functional changes in the neural activity within the brain's sensorimotor network, which in turn are related to the characteristic motor symptoms in PD. The functional changes in PD are particularly prominent in terms of oscillatory neuronal activity in the characteristic sensorimotor alpha and beta rhythms. However, summaries in terms of alpha or beta power do not capture the full range of the complex dynamic nature of the signals from the somatosensory cortex. This raises the question of how to quantify and summarise the functional changes in such oscillatory features in a manner that captures the relevant disease- and symptom-related neural activity.

We investigated the role of spontaneous cortical somatosensory activity in the electrophysiological alpha and beta bands among a cohort of early- to mid-stage PD patients $(\mathrm{N}=78)$ and age- and gender-matched healthy controls ( $N=60)$ using source reconstructed resting-state magnetoencephalography (MEG) recordings. We quantified the oscillatory features of the neural time series by its oscillatory alpha power, beta power, and $1 / f$ broadband characteristics using power spectral density, and additionally by characterising "burst" properties in the signals. We examined the relationship between the signal features and disease state, age, sex, and cortical thickness. Using multiple regression, we examined the relative contribution of the oscillatory features on the clinical manifestation of motor symptoms in the PD group.

Our results show that PD patients differ from healthy controls on several of the oscillatory features, showing higher beta-band power, higher burst amplitude, and steeper $1 / \mathrm{f}$ broadband characteristics compared to healthy controls, as well as a steeper age-related decrease in the bursts rate. While there was a high degree of correlation between some of the oscillatory features, several features also appeared functionally separated, 
medRxiv preprint doi: https://doi.org/10.1101/2021.06.27.21259592; this version posted June 30, 2021. The copyright holder for this preprint (which was not certified by peer review) is the author/funder, who has granted medRxiv a license to display the preprint in perpetuity.

It is made available under a CC-BY 4.0 International license .

showing independent feature-to-symptom relationships. For instance, oscillatory beta power increased with the severity of midline function symptoms, while burst rate decreased with the severity of bradykinesia.

Our study shows that quantification of distinct features within the oscillatory sensorimotor neural time series in PD captures different underlying mechanisms related to disease progression and symptom severity, which in turn has a potential for a more individualised and precision-based approach to assessing functional neural changes in PD. 
medRxiv preprint doi: https://doi.org/10.1101/2021.06.27.21259592; this version posted June 30, 2021. The copyright holder for this preprint (which was not certified by peer review) is the author/funder, who has granted medRxiv a license to display the preprint in perpetuity.

It is made available under a CC-BY 4.0 International license .

\section{Introduction}

2 Parkinson's disease (PD) is a common neurodegenerative disease characterised by gradual death of

3 dopaminergic neurons and loss of the neurotransmitter dopamine. ${ }^{1,2}$ The pathogenesis of PD begins long before the initial manifestation of symptoms and gradually deteriorates from the initial stages. Accumulation of Lewy bodies leads to lesions in the substantia nigra pars compacta, which typically spread to and affect the brain stem, basal ganglia and, in the final stages, the neocortex. ${ }^{3}$ The progressive structural and neurochemical changes in PD are accompanied by widespread functional changes in neuronal activity, which in turn lead to worsening clinical symptoms, commonly in the form of movement disorders such as tremor, rigidity, and bradykinesia with co-occurring non-motor systems like sleep disorders, depression, fatigue, and cognitive deficits. ${ }^{1}$

The changes in brain function in PD are particularly prominent in the oscillatory activity of neurons. ${ }^{4}$ Spontaneous oscillatory beta band $(13-30 \mathrm{~Hz})$ activity in the sub-thalamic nucleus (STN) exhibits a systematic disease-related increase in synchronicity in PD that is related to the dopamine leve $\mathrm{I}^{5-8}$, and correlated with the severity of bradykinesia and rigidity., ${ }^{9,10}$ Changes in the beta band extend beyond the STN through the basal ganglia-thalamic cortical sensorimotor network.

The cortical manifestation of the disease-related changes in the sensorimotor network can be measured noninvasively from the cortex, using electro- or magnetoencephalography (EEG or MEG). Non-invasive neural recordings can potentially provide prospective biomarkers of disease or symptom-related neural changes in PD. Increased oscillatory beta-band activity in the sensorimotor cortex has been linked to increased symptom severity, such as rigidity and bradykinesia. ${ }^{11,12}$ The cortical beta-band power has also been shown to increase by dopaminergic medication ${ }^{13-15}$, though others have found no effect of medication on cortical beta-band power. ${ }^{11,16,17}$ Deep brain stimulation of the STN in PD patients has shown to lead to a decrease in the power of 
medRxiv preprint doi: https://doi.org/10.1101/2021.06.27.21259592; this version posted June 30, 2021. The copyright holder for this preprint (which was not certified by peer review) is the author/funder, who has granted medRxiv a license to display the preprint in perpetuity.

It is made available under a CC-BY 4.0 International license.

spontaneous activity in the cortical sensorimotor beta and alpha $(8-12 \mathrm{~Hz})$ bands ${ }^{18,19}$ (but see also $\left.{ }^{13,20}\right)$.

Importantly, there is evidence that the beta-band changes are not in the same direction across the different stages of PD. For example, there are reports of increased cortical beta-band power in the early stages of PD ${ }^{21}$, whereas the later stages are associated with decreased beta-band power. ${ }^{22}$

The beta-band power is not the only feature of the sensorimotor rhythms that is altered in PD. Several studies have found a shift in the beta-band centre frequency (the frequency at which the power spectrum density peaks in the beta-band) towards a lower frequency in PD patients compared to healthy controls. ${ }^{23-25}$ The shift towards lower beta-band centre frequency is more pronounced in PD patients with dementia ${ }^{26-29}$ and correlates with reduced cognitive ability. ${ }^{25,30}$ Notably, the centre frequency shift is detectable already in the early stages of $\mathrm{PD}^{24}$, and dopaminergic medication does not appear to affect the centre frequency shift. ${ }^{31}$ The changes in beta band power and centre frequency in PD could indicate that different features of the oscillatory beta-band activity reflect different underlying neural functions expressed in the measured sensorimotor signals. Changes in beta-band power could be functionally related to sensorimotor disturbances, and changes in centre frequency could be related to cognitive function.

Notably, the characteristics of neuronal oscillatory activity may hold additional information of disease-related changes in PD. Both beta-band power and centre frequency reflect a quantification of power spectral density (PSD). While these features can provide valuable information about disease-related changes in PD, the quantification of a neural time series by the PSD provides a static summary of the oscillatory activity across the entire time series. PSD does not account for inherent dynamics in this activity or changes in the time series on shorter time scales-as is prevalent in neural time series. The beta-band exhibits a great degree of variation over time and contains characteristic high-amplitude "bursts" that last about 50-200 ms, both in the cortical and sub-cortical beta-band. ${ }^{32-35}$ Functionally, the transient bursts appear to play a pivotal role in sensorimotor processing through the basal ganglia-thalamic-cortical network. For instance, the presence of a beta burst in 
medRxiv preprint doi: https://doi.org/10.1101/2021.06.27.21259592; this version posted June 30, 2021. The copyright holder for this preprint (which was not certified by peer review) is the author/funder, who has granted medRxiv a license to display the preprint in perpetuity.

It is made available under a CC-BY 4.0 International license .

the sensorimotor cortex close to a tactile stimulation decreased the likelihood of tactile detection ${ }^{36}$, and the rate of beta bursts is shown to decrease in the time leading up to a movement both in $\mathrm{STN}^{37-39}$ and in the sensorimotor cortex. ${ }^{40}$

In PD, quantification of beta-band burst activity from recordings in the STN has shown that beta-burst rate and duration are reduced by dopaminergic medication ${ }^{41,42}$ and deep brain stimulation. ${ }^{35}$ Furthermore, at the cortical level, PD patients exhibit a decrease in the rate of beta burst compared to healthy controls. ${ }^{17}$ This decrease in beta burst rate scale with increased severity of bradykinesia and postural-kinetic tremor symptoms but does not change as an effect of dopaminergic medication. ${ }^{17}$ Notably, the burst rate showed a higher sensitivity than PSD beta power for discriminating PD patients from healthy controls, demonstrating that the choice of method for beta-band characterisation directly influences the sensitivity of subsequent analyses.

In sum, there is solid evidence of functional changes in the oscillatory sensorimotor neural activity in PDwhether assessed as PSD band power, peak shift or burst rate. The measures differ between PD patients and healthy controls and scale with PD symptom severity. Sensorimotor activity measured non-invasively with MEG/EEG contains rich information about the functional state of the sensorimotor system and how this changes in PD. The central challenge is quantifying the measured neural signals to extract the disease's relevant features from the signals, be it the spectral power, centre frequencies, or burst-like features. This is further complicated by the fact that in addition to disease-related changes, these features likely differ with age, and the available data come from studies with small sizes-typically in the range of 5-30 participants. ${ }^{43}$

In the current study, we aimed to compare how different oscillatory features of cortical sensorimotor activity change in PD to elucidate what oscillatory features in the neural time-series differ between PD patients and healthy controls and how these features are associated with different motor symptoms in PD. We extracted the sensorimotor neural resting-state activity from source reconstructed resting-state MEG signals in the sensorimotor cortex (Figure 1) and quantified the time-series in terms of the PSD in the canonical mu-band, 
medRxiv preprint doi: https://doi.org/10.1101/2021.06.27.21259592; this version posted June 30, 2021. The copyright holder for this preprint (which was not certified by peer review) is the author/funder, who has granted medRxiv a license to display the preprint in perpetuity.

It is made available under a CC-BY 4.0 International license .

consisting of the sensorimotor alpha $(8-12 \mathrm{~Hz})$ and beta $(13-30 \mathrm{~Hz})$ bands. The two frequency components of the mu band are co-occurring in the sensorimotor areas but appear to be functionally independent. ${ }^{44,45}$ In addition to the band-specific analysis, we compared the $1 / \mathrm{f}$ broadband characteristics of the PSD. ${ }^{46,47}$ Finally, we compared features of the sensorimotor rhythm in terms of time-domain analysis of spontaneous transient bursts. ${ }^{17,36}$ We tested this hypothesis by analysing how these features differed between PD patients and healthy controls and how the difference interacted with age and sex. As ageing is associated with structural and functional changes in the sensorimotor cortex ${ }^{48,49}$, we investigated if the potential changes in sensorimotor activity in PD differ across age. Since both healthy ageing and PD disease progression are linked to thinning of the cortex ${ }^{50}$, we further included thickness of the sensorimotor cortex in the analysis.

The central hypothesis was that there would be differences in features of the sensorimotor signals, but different features may be related to different functional changes. We hypothesised that individual oscillatory features would reflect different underlying neural function in the sensorimotor system and thereby show different relationships to the clinical manifestations of specific motor symptoms in PD. We tested this hypothesis in two steps: first by examining the inter-relationship between all different measures, and subsequently by examining what feature-or combination of features-best explained the variation in severity within each motor symptoms.

To enable a sensitive assessment of disease-related oscillatory changes in PD, we aimed for a large cohort of PD patients $(\mathrm{N}=78)$ and healthy controls $(\mathrm{N}=60)$, balanced across gender and age, and with gender- and agematched groups (Table 1). 
medRxiv preprint doi: https://doi.org/10.1101/2021.06.27.21259592; this version posted June 30, 2021. The copyright holder for this preprint (which was not certified by peer review) is the author/funder, who has granted medRxiv a license to display the preprint in perpetuity.

It is made available under a CC-BY 4.0 International license.

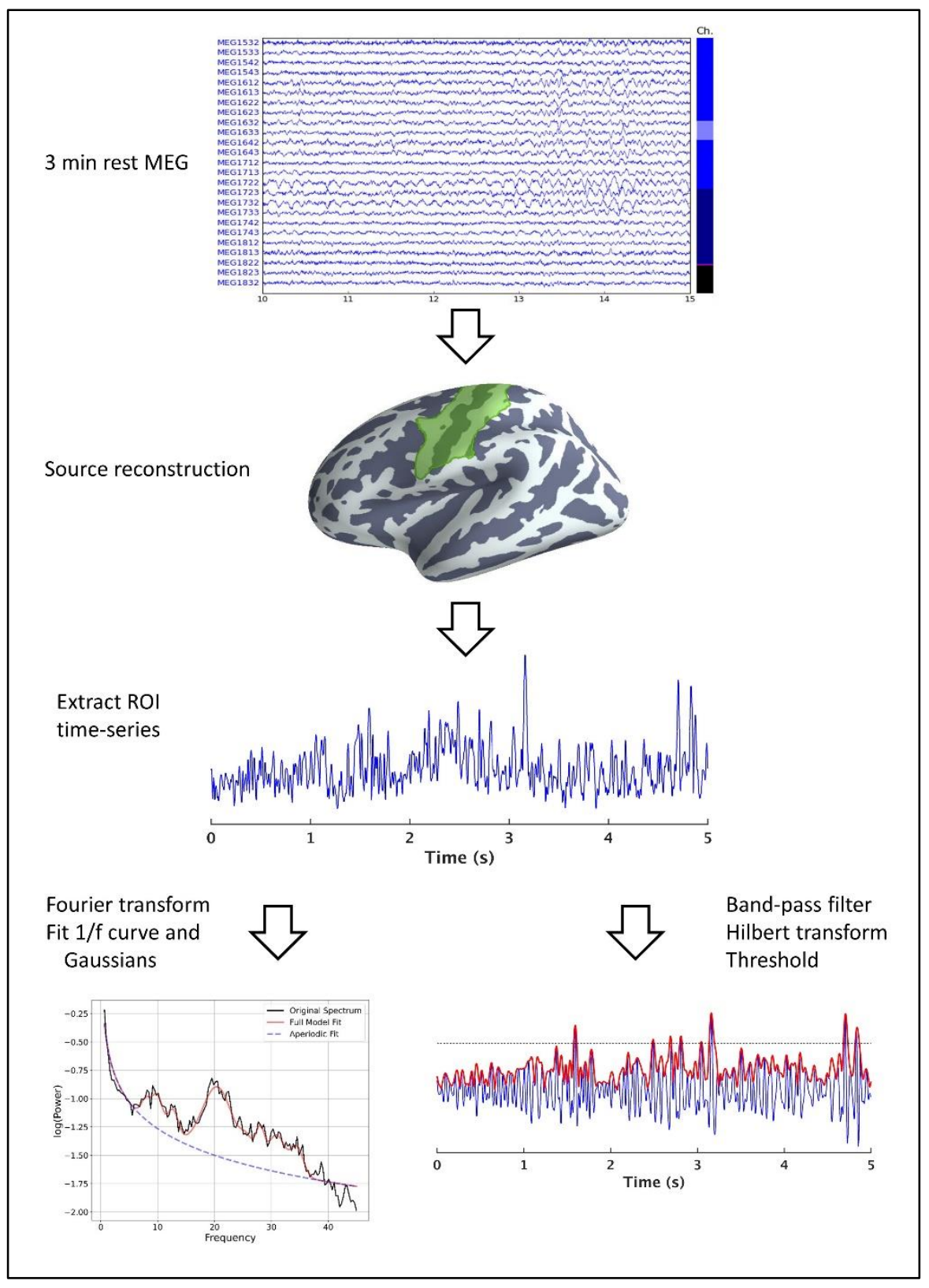

Figure 1: Overview of the data processing pipeline from three minutes raw resting-state MEG, through series in the sensorimotor ROI. 
medRxiv preprint doi: https://doi.org/10.1101/2021.06.27.21259592; this version posted June 30, 2021. The copyright holder for this preprint (which was not certified by peer review) is the author/funder, who has granted medRxiv a license to display the preprint in perpetuity.

It is made available under a CC-BY 4.0 International license.

\section{Results}

95 The main analyses tested the effect of group (PD patients/healthy controls; Table 1), age, sex, and cortical

thickness in the sensorimotor cortex on the features explained in Table 2. Second, we tested for associations

97 between the clinical rating of motor symptoms in the PD group by a multiple regression analysis including the sensorimotor signal features in Table 2 and age, sex, and cortical thickness to regress out the contribution hereof and estimate the relative effect size of each signal feature. Figure 2 displays the PSD of the sensorimotor signal.

101 Table 1: Group-level summary of the participants included in the analysis. Mean (standard deviation).

\begin{tabular}{|l|l|l|l|}
\hline Measure & Parkinson's patients & Healthy controls & Statistics \\
\hline$N$ & 78 & 60 & \\
\hline Sex (female/male) & $29 / 49$ & $27 / 33$ & $\chi^{2}=0.57, \mathrm{p}=0.45$ \\
\hline Age & $65.6(9.5)$ & $63.93(8.4)$ & Welsh $\mathrm{t}(138.0)=1.08, \mathrm{p}=0.28$ \\
\hline Disease duration & $4.4(3.7)$ years & - & - \\
\hline LEDD & $548(273) \mathrm{mg}$ & - & - \\
\hline MDS-UPDRS-III & $18.9(10.8)$ & - & - \\
\hline MoCA & $26.1(2.8)$ & $26.2(2.1)$ & Welsh $\mathrm{t}(136)=0.10, \mathrm{p}=0.92$ \\
\hline
\end{tabular}


medRxiv preprint doi: https://doi.org/10.1101/2021.06.27.21259592; this version posted June 30, 2021. The copyright holder for this preprint (which was not certified by peer review) is the author/funder, who has granted medRxiv a license to display the preprint in perpetuity.

It is made available under a CC-BY 4.0 International license .

Table 2: Explanation of the main outcome variables in the analysis

\begin{tabular}{|c|c|c|}
\hline $\begin{array}{l}\text { Variable } \\
\text { Category }\end{array}$ & Variable & Explanation \\
\hline \multirow{8}{*}{ PSD } & Beta power & $\begin{array}{l}\text { The maximum peak in the } 13-30 \mathrm{~Hz} \text { band. Estimated as the height of the Gaussian } \\
\text { function fitted to the PSD after regressing out the } 1 / \mathrm{f} \text { regression line. }\end{array}$ \\
\hline & Beta centre & The dominant frequency bin in the $13-30 \mathrm{~Hz}$ band. Estimated as the mean of the \\
\hline & frequency $(\mathrm{Hz})$ & Gaussian function fitted to the PSD after regressing out the $1 / \mathrm{f}$ regression line \\
\hline & Alpha power & $\begin{array}{l}\text { The maximum peak in the } 8-12 \mathrm{~Hz} \text { band. Estimated as the height of the Gaussian } \\
\text { function fitted to the PSD after regressing out the } 1 / \mathrm{f} \text { regression line. }\end{array}$ \\
\hline & Alpha centre & The dominant frequency bin in the $8-12 \mathrm{~Hz}$ band. Estimated as the mean of the \\
\hline & frequency $(\mathrm{Hz})$ & Gaussian function fitted to the PSD after regressing out the $1 / \mathrm{f}$ regression line. \\
\hline & $1 /$ fintercept & $\begin{array}{l}\text { The intercept of the log-linear regression estimated from the full PSD in the } 0.5-40 \\
\mathrm{~Hz} \text { range. }\end{array}$ \\
\hline & $1 / f$ exponent & $\begin{array}{l}\text { The exponent of the log-linear regression-corresponding to the slope of the log- } \\
\text { log transformed PSD-estimated from the full PSD in the } 0.5-40 \mathrm{~Hz} \text { range }\end{array}$ \\
\hline \multirow{4}{*}{ Bursts } & Rate & $\begin{array}{l}\text { The number of burst events in the sensorimotor time series divided by the length } \\
\text { of time series. }\end{array}$ \\
\hline & Duration (ms) & $\begin{array}{l}\text { Duration of the burst events defined as the time the time-series is above threshold } \\
\text { until the next time-point it drops below the threshold. }\end{array}$ \\
\hline & Interval (ms) & $\begin{array}{l}\text { Time from the } \mathrm{mu} / \text { beta time-series drops below threshold until the next time- } \\
\text { point it reaches threshold again. }\end{array}$ \\
\hline & Amplitude & The maximum amplitude of the mu/beta time-series within one burst event. \\
\hline
\end{tabular}

\section{5}

\subsection{Differences in PSD features between groups}

106 For the first analysis, we wanted to examine if PSD features differed between PD patients and healthy controls and how this might interact with sex, age and cortical thickness. The model parameters and statistical 
medRxiv preprint doi: https://doi.org/10.1101/2021.06.27.21259592; this version posted June 30, 2021. The copyright holder for this preprint (which was not certified by peer review) is the author/funder, who has granted medRxiv a license to display the preprint in perpetuity.

It is made available under a CC-BY 4.0 International license .

Variable category

\begin{tabular}{|c|c|c|c|c|c|c|}
\hline \multirow{2}{*}{ Variabie category } & \multicolumn{6}{|c|}{ roviteatures } \\
\hline & $\begin{array}{l}\text { Beta } \\
\text { power }\end{array}$ & $\begin{array}{l}\text { Beta } \\
\text { centre freq. }\end{array}$ & $\begin{array}{l}\text { Alpha } \\
\text { power }\end{array}$ & $\begin{array}{l}\text { Alpha } \\
\text { centre freq. }\end{array}$ & $\begin{array}{l}1 / \mathrm{f} \\
\text { intercept }\end{array}$ & $\begin{array}{l}1 / \mathrm{f} \\
\text { exponent }\end{array}$ \\
\hline \multirow[t]{3}{*}{ Intercept } & 0.291 & 21.3 & 0.291 & 10.5 & -1.34 & 0.64 \\
\hline & LL: 0.250 & LL: 19.8 & LL: 0.234 & LL: 9.89 & LL: -1.47 & LL: 0.59 \\
\hline & UL: 0.331 & UL: 22.9 & UL: 0.353 & UL: 11.2 & UL: -1.21 & UL: 0.69 \\
\hline \multirow[t]{3}{*}{ Group } & 0.070 & -0.945 & 0.040 & -0.643 & 0.31 & 0.08 \\
\hline & LL: 0.019 & LL: -3.17 & LL: -0.044 & LL: -1.63 & LL: 0.13 & LL: 0.00 \\
\hline & UL: 0.126 & UL: 1.35 & UL: 0.118 & UL: 0.276 & UL: 0.50 & UL: 0.15 \\
\hline \multirow[t]{3}{*}{ Age } & -0.001 & -0.098 & 0.000 & 0.048 & 0.01 & -0.000 \\
\hline & LL: -0.005 & LL: -0.259 & LL: -0.007 & LL: -0.032 & LL: -0.01 & LL: -0.01 \\
\hline & UL: 0.004 & UL: 0.082 & UL: 0.006 & UL: 0.123 & UL: 0.02 & UL: 0.01 \\
\hline \multirow[t]{3}{*}{ Sex } & -0.006 & -1.04 & -0.043 & -0.174 & 0.07 & 0.02 \\
\hline & LL: -0.061 & LL: -3.013 & LL: -0.124 & LL: -1.10 & LL: -0.10 & LL: -0.05 \\
\hline & UL: 0.045 & UL: 0.944 & UL: 0.029 & UL: 0.713 & UL: 0.24 & UL: 0.10 \\
\hline \multirow[t]{3}{*}{ Cortical Thickness } & -0.020 & 0.544 & 0.021 & 0.305 & -0.06 & -0.02 \\
\hline & LL: -0.064 & LL: -1.01 & LL: - 0.052 & LL: -0.452 & LL: -0.21 & LL: -0.08 \\
\hline & UL: 0.022 & UL: 2.27 & UL: 0.089 & UL: 1.08 & UL: 0.09 & UL: 0.03 \\
\hline \multirow[t]{3}{*}{ Group:Age } & 0.002 & -0.022 & -0.001 & -0.064 & 0.000 & 0.005 \\
\hline & LL: -0.004 & LL: -0.299 & LL: -0.012 & LL: -0.185 & LL: -0.02 & LL: -0.01 \\
\hline & UL: 0.009 & UL: 0.243 & UL: 0.010 & UL: 0.066 & UL: 0.02 & UL: 0.01 \\
\hline \multirow[t]{3}{*}{ Group:Sex } & -0.056 & 1.08 & -0.016 & 0.559 & -0.19 & -0.02 \\
\hline & LL: -0.130 & LL: -1.89 & LL: -0.118 & LL: -0.619 & LL: -0.43 & LL: -0.12 \\
\hline & UL: 0.0151 & UL: 3.80 & UL: 0.095 & UL: 1.91 & UL: 0.04 & UL: 0.08 \\
\hline \multirow[t]{3}{*}{ Group: Cortical Thickness } & 0.016 & -0.678 & -0.049 & -0.46 & 0.04 & 0.02 \\
\hline & LL: -0.042 & LL: - 2.97 & LL: -0.140 & LL: -1.54 & LL: -0.14 & LL: -0.06 \\
\hline & UL: 0.076 & UL: 1.58 & UL: 0.037 & UL: 0.648 & UL: 0.24 & UL: 0.10 \\
\hline \multirow[t]{3}{*}{ Age:Sex } & -0.001 & 0.193 & 0.000 & 0.005 & -0.001 & 0.001 \\
\hline & LL: -0.007 & LL: -0.051 & LL: -0.010 & LL: -0.110 & LL: -0.02 & LL: -0.01 \\
\hline & UL: 0.006 & UL: 0.435 & UL: 0.009 & UL: 0.117 & UL: 0.02 & UL: 0.01 \\
\hline \multirow[t]{3}{*}{ Age: Cortical Thickness } & 0.002 & 0.062 & 0.003 & -0.021 & -0.01 & -0.003 \\
\hline & LL: -0.002 & LL: -0.103 & LL: -0.004 & LL: -0.104 & LL: -0.02 & LL: -0.01 \\
\hline & UL: 0.006 & UL: 0.230 & UL: 0.010 & UL: 0.065 & UL: 0.01 & UL: 0.00 \\
\hline \multirow[t]{3}{*}{ Sex: Cortical Thickness } & 0.032 & -0.476 & 0.015 & 0.255 & 0.05 & 0.000 \\
\hline & LL: -0.022 & LL: -2.71 & LL: -0.078 & LL: -0.820 & LL: -0.15 & LL: -0.08 \\
\hline & UL: 0.089 & UL: 1.95 & UL: 0.110 & UL: 1.34 & UL: 0.25 & UL: 0.08 \\
\hline \multirow[t]{3}{*}{ Group: Age: Sex } & 0.001 & -0.160 & 0.002 & -0.045 & -0.01 & -0.004 \\
\hline & LL: -0.007 & LL: -0.493 & LL: -0.012 & LL: -0.206 & LL: -0.04 & LL: -0.02 \\
\hline & UL: 0.010 & UL: 0.186 & UL: 0.016 & UL: 0.115 & UL: 0.02 & UL: 0.01 \\
\hline \multirow[t]{3}{*}{ Group: Age: Cortical Thickness } & 0.003 & -0.053 & 0.000 & -0.008 & 0.02 & 0.01 \\
\hline & LL: -0.003 & LL: -0.270 & LL: -0.008 & LL: -0.110 & LL: -0.01 & LL: -0.00 \\
\hline & UL: 0.008 & UL: 0.163 & UL: 0.008 & UL: 0.087 & UL: 0.025 & UL: 0.01 \\
\hline \multirow[t]{3}{*}{ Group: Sex: Cortical Thickness } & -0.043 & 0.948 & -0.007 & -0.028 & -0.04 & -0.02 \\
\hline & LL: -0.124 & LL: -2.11 & LL: -0.126 & LL: - 1.46 & LL: -0.30 & LL: -0.13 \\
\hline & UL: 0.028 & UL: 4.043 & UL: 0.104 & UL: 1.43 & UL: 0.22 & UL: 0.08 \\
\hline \multirow[t]{3}{*}{ Age: Sex: Cortical Thickness } & -0.007 & 0.076 & -0.006 & 0.080 & 0.005 & -0.005 \\
\hline & LL: -0.012 & LL: -0.125 & LL: -0.013 & LL: -0.016 & LL: -0.01 & LL: -0.01 \\
\hline & UL: -0.002 & UL: 0.267 & UL: 0.001 & UL: 0.169 & UL: 0.02 & UL: 0.00 \\
\hline
\end{tabular}

Burst features

\begin{tabular}{|c|c|c|c|}
\hline Rate & Length & Interval & Amplitude \\
\hline 3.60 & -3.40 & -0.27 & 0.59 \\
\hline LL: 3.54 & LL: -3.47 & LL: -0.40 & LL: 0.46 \\
\hline UL: 3.67 & UL: - 3.33 & UL: -0.13 & UL: 0.71 \\
\hline-0.005 & 0.002 & -0.05 & 0.34 \\
\hline LL: -0.10 & LL: -0.10 & LL: -0.24 & LL: 0.17 \\
\hline UL: 0.09 & UL: 0.10 & UL: 0.14 & UL: 0.53 \\
\hline 0.009 & -0.001 & -0.01 & 0.01 \\
\hline LL: 0.001 & LL: -0.01 & LL: -0.02 & LL: -0.01 \\
\hline UL: 0.02 & UL: 0.01 & UL: 0.01 & UL: 0.02 \\
\hline-0.15 & -0.10 & 0.16 & 0.05 \\
\hline LL: -0.23 & LL: -0.20 & LL: -0.01 & LL: -0.12 \\
\hline UL: -0.06 & UL: -0.01 & UL: 0.33 & UL: 0.21 \\
\hline-0.083 & -0.02 & 0.09 & -0.06 \\
\hline LL: -0.16 & LL: -0.10 & LL: -0.04 & LL: -0.19 \\
\hline UL: -0.013 & UL: 0.05 & UL: 0.23 & UL: 0.07 \\
\hline-0.015 & -0.01 & 0.01 & -0.001 \\
\hline LL: -0.03 & LL: -0.02 & LL: -0.01 & LL: -0.02 \\
\hline UL: -0.003 & UL: 0.01 & UL: 0.03 & UL: 0.02 \\
\hline 0.09 & 0.06 & -0.09 & -0.25 \\
\hline LL: -0.03 & LL: -0.06 & LL: -0.34 & LL: -0.47 \\
\hline UL: 0.20 & UL: 0.20 & UL: 0.16 & UL: -0.02 \\
\hline 0.02 & 0.04 & -0.04 & 0.06 \\
\hline LL: -0.08 & LL: -0.07 & LL: -0.21 & LL: -0.12 \\
\hline UL: 0.12 & UL: 0.14 & UL: 0.15 & UL: 0.23 \\
\hline-0.01 & -0.001 & 0.02 & -0.003 \\
\hline LL: -0.02 & LL: -0.01 & LL: -0.01 & LL: -0.02 \\
\hline UL: 0.00 & UL: 0.01 & UL: 0.04 & UL: 0.02 \\
\hline 0.001 & -0.000 & 0.001 & -0.001 \\
\hline LL: -0.01 & LL: -0.01 & LL: -0.01 & LL: -0.01 \\
\hline UL: 0.01 & UL: 0.01 & UL: 0.02 & UL: 0.01 \\
\hline 0.08 & 0.02 & -0.07 & 0.11 \\
\hline LL: -0.03 & LL: -0.08 & LL: -0.28 & LL: -0.08 \\
\hline UL: 0.19 & UL: 0.13 & UL: 0.12 & UL: 0.29 \\
\hline 0.01 & -0.000 & -0.01 & -0.01 \\
\hline LL: -0.01 & LL: -0.02 & LL: -0.04 & LL: -0.03 \\
\hline UL: 0.02 & UL: 0.02 & UL: 0.02 & UL: 0.02 \\
\hline-0.00 & 0.01 & -0.003 & 0.003 \\
\hline LL: -0.01 & LL: -0.00 & LL: -0.02 & LL: -0.01 \\
\hline UL: 0.01 & UL: 0.02 & UL: 0.01 & UL: 0.02 \\
\hline-0.01 & -0.06 & 0.05 & -0.11 \\
\hline LL: -0.15 & LL: -0.20 & LL: -0.23 & LL: -0.34 \\
\hline UL: 0.13 & UL: 0.08 & UL: 0.29 & UL: 0.14 \\
\hline 0.005 & -0.001 & -0.005 & 0.01 \\
\hline LL: -0.00 & LL: -0.01 & LL: -0.02 & LL: -0.01 \\
\hline UL: 0.01 & UL: 0.01 & UL: 0.01 & UL: 0.02 \\
\hline
\end{tabular}


medRxiv preprint doi: https://doi.org/10.1101/2021.06.27.21259592; this version posted June 30, 2021. The copyright holder for this preprint (which was not certified by peer review) is the author/funder, who has granted medRxiv a license to display the preprint in perpetuity.

It is made available under a CC-BY 4.0 International license .

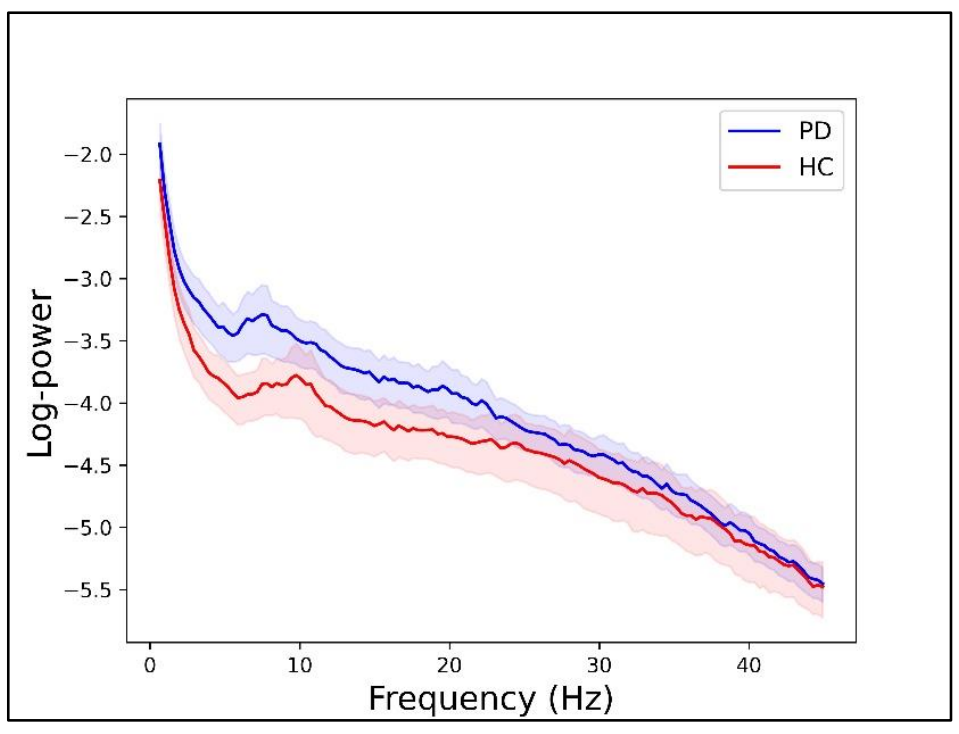

Figure 2: Grand average PSD (mean+se) for the PD group (blue) and healthy control group (red).

\section{$115 \quad 2.1 .1$ Beta power}

116 The PSD beta power showed significant effects of group $\left(\chi^{2}(1)=5.42 ; p=0.020\right)$, age $\left(\chi^{2}(1)=4.00 ; p=0.46\right)$ and

117 the three-way interaction between age, sex, and cortical thickness $\left(\chi^{2}(1)=8.05 ; p=0.005\right)$. The relative effect

118 of group corresponded to an increase in beta power of $23.8 \%$ [Cl: $3.6: 48.5]$ for PD patients. The relative effect

119 of age corresponded to a relative change of $-0.2 \%$ per year of age (Figure 3 ). The direction of interaction three-

120 way interaction between age, sex, and cortical thickness indicated that higher cortical thickness was associated

121 with a steeper decrease in beta power, with a larger decrease in beta power in older ages for males compared

122 to females.

\section{$123 \quad$ 2.1.2 Beta centre frequency}

124 There were no significant effects of any predictor on beta centre frequency.

\section{$125 \quad 2.1 .3 \quad$ Alpha power}

126 There were no significant effects of any predictor on PSD alpha power. 
medRxiv preprint doi: https://doi.org/10.1101/2021.06.27.21259592; this version posted June 30, 2021. The copyright holder for this preprint (which was not certified by peer review) is the author/funder, who has granted medRxiv a license to display the preprint in perpetuity.

It is made available under a CC-BY 4.0 International license .

127

128

129

\subsubsection{Alpha centre frequency}

The analysis of alpha centre frequency showed a significant interaction between group and age $\left(\chi^{2}(1)=5.82 ; p\right.$ $=0.016)$ and a significant interaction between group and cortical thickness $\left(\chi^{2}(1)=3.95 ; p=0.047\right)$. The agerelated differences in alpha centre frequency increased by $0.05 \mathrm{~Hz}$ [Cl: $-0.03: 0.12]$ per year of age for healthy controls. The difference was $-0.02 \mathrm{~Hz}$ [Cl: $-0.11: 0.08]$ per year of age for PD patients. Higher cortical thickness was associated with a $0.30 \mathrm{~Hz}$ [Cl: $-0.45: 1.08]$ difference in alpha centre frequency per standardised unit increase in cortical thickness for healthy controls and a difference of $-0.16 \mathrm{~Hz}$ [Cl: $-0.80: 0.60]$ per standardised unit increase in cortical thickness for PD patients.

\subsubsection{Broadband $1 /$ f intercept}

The $1 / f$ intercept of the PSD spectrum showed a significant effect of group $(\chi 2(1)=12.19 ; p=0.0005)$ and interaction between Group and $\operatorname{Sex}(\chi 2(1)=4.41 ; p=0.036)$. The $1 / f$ intercept were $23.5 \%$ [Cl: $10.5: 35.3]$ higher for female PD patients compared to female healthy controls and 9.5\% [Cl: -2.0:26.1] higher for male PD patients compared to male healthy controls. Male PD patients had $-12.1 \%$ [Cl: $-30.4: 3.8]$ lower $1 / \mathrm{f}$ intercepts compared to female PD patients. Male healthy controls showed a slight increase in PSD intercept of 5.3\% [CI: 8.1:16:4] compared to female healthy controls.

\subsubsection{Broadband $1 / \mathrm{f}$ exponent}

The analysis of the $1 / f$ exponent or the PSD showed a significant effect of group $(\chi 2(1)=8.48 ; p=0.003)$ and a significant effect of cortical thickness $(\chi 2(1)=6.02 ; p=0.014)$.

PD patients had relative steeper decay with $11.9 \%$ [Cl: 1.0:26.1\%] higher $1 / \mathrm{f}$ exponent than healthy controls. Higher cortical thickness was associated with a $-3.6 \%$ [Cl: $-12.8: 5.5]$ difference in $1 / \mathrm{f}$ exponent per standardised unit increase in cortical thickness (Figure 3). 
medRxiv preprint doi: https://doi.org/10.1101/2021.06.27.21259592; this version posted June 30, 2021. The copyright holder for this preprint (which was not certified by peer review) is the author/funder, who has granted medRxiv a license to display the preprint in perpetuity.

It is made available under a CC-BY 4.0 International license .

148

149

150

151

152

153

154

155

156

157

158

159

160

161

162

163

164

165

166

167

168

169

\subsection{Differences in burst features between groups}

\subsubsection{Burst rate}

The analysis of burst per minute showed main effects of age $\left(\chi^{2}(1)=5.10 ; p=0.024\right)$ and $\operatorname{sex}\left(\chi^{2}(1)=7.86 ; p=\right.$ $0.038)$ as well as interactions between group and age $\left(\chi^{2}(1)=11.74 ; p=0.001\right)$, age and $\operatorname{sex}\left(\chi^{2}(1)=5.39 ; p=\right.$ $0.020)$, age and cortical thickness $\left(\chi^{2}(1)=6.55 ; p=0.010\right)$, and sex and cortical thickness $\left(\chi^{2}(1)=4.35 ; p=\right.$ 0.037).

The age-related effect corresponded to a lower burst rate of $-0.7 \%[\mathrm{Cl}:-1.5: 0.3]$ per year for female PD patients and $-0.9 \%$ [Cl: $-1.4:-0.4]$ lower rate per year for male PD patients, whereas female controls had a relative increase in burst rate of $0.9 \%[\mathrm{Cl}: 0.1: 1.6]$ per year and male controls had a stable trend of $-0.2 \%$ [Cl: $-0.9: 0.6]$ per year. The interaction between sex and cortical thickness showed a relative difference of $-8.0 \%$ [Cl: -14.4:1.7] per standardised unit increase in cortical thickness for females but did not vary across age for men with an estimated relative difference of $-0.8 \%$ [Cl: -8.1:6.7] per standardised unit increase in cortical thickness (Figure 3). The direction of the interaction between age and cortical thickness meant that thicker cortex was associated with an additional relative difference in burst rate per year of age of $-7.1 \%$ [Cl: -13.5:-0.7] per standardised unit increase in cortical thickness.

\subsubsection{Burst duration}

The mixed-model analysis of burst duration revealed a group-level main effect of age $\left(\chi^{2}(1)=7.83 ; p=0.005\right)$ and $\operatorname{sex}\left(\chi^{2}(1)=4.32 ; p=0.038\right)$ and an effect of the interaction between age and cortical thickness $\chi^{2}(1)=4.10$; $p=0.043)$. The relative effect of sex showed that men had an overall 9.8\% [Cl: -18.3:-1.1] shorter burst duration than females. The age-related difference in burst duration corresponded to a difference of $0.14 \%$ [0.9:0.7] per year of age. The age-related difference was further modified by $-2.1 \%$ [Cl: $-13.5:-0.7]$ per standardised unit increase in cortical thickness. 
medRxiv preprint doi: https://doi.org/10.1101/2021.06.27.21259592; this version posted June 30, 2021. The copyright holder for this preprint (which was not certified by peer review) is the author/funder, who has granted medRxiv a license to display the preprint in perpetuity.

It is made available under a CC-BY 4.0 International license .

\subsubsection{Burst interval}

171 The mixed-model analysis of the burst interval only showed significant main effect of age $\left(\chi^{2}(1)=6.52 ; p=\right.$

$1720.011)$ and interaction between age and $\operatorname{sex}\left(\chi^{2}(1)=4.41 ; p=0.036\right)$. The model predicted a relative difference

173 in interval per year of age of $-0.6 \%$ [Cl: $-2.1: 0.9]$ for females and difference of $1.0 \%[\mathrm{Cl}:-0.6: 2.5]$ per year of age

174 for males.

\section{$175 \quad 2.2 .4$ Burst amplitude}

176 The mixed-model analysis of burst amplitudes showed a significant main effect of group $\left(\chi^{2}(1)=10.94 ; p=\right.$

$1770.0009)$ and interaction between group and $\operatorname{sex}\left(\chi^{2}(1)=6.35 ; p=0.012\right)$. Female PD patients had on average

$17841.0 \%$ [Cl: 18.0:68.3] higher burst amplitude than female controls, while male PD patients had 15.6\% [Cl: -

$1792.2: 35.7 \%]$ higher burst amplitude than male controls. Male PD patients had a relative lower burst amplitude

180 than female PD patients of $-18.0 \%$ [Cl: -29.8:-3.3] compared to a negligible relative amplitude difference of $5.3 \%[\mathrm{Cl}:-10.1: 22.8]$ between male and females healthy controls. 
medRxiv preprint doi: https://doi.org/10.1101/2021.06.27.21259592; this version posted June 30, 2021. The copyright holder for this preprint (which was not certified by peer review) is the author/funder, who has granted medRxiv a license to display the preprint in perpetuity.

It is made available under a CC-BY 4.0 International license .

182

183

184

185

186

187

188

189

190

191

192

193

194

195

196

197
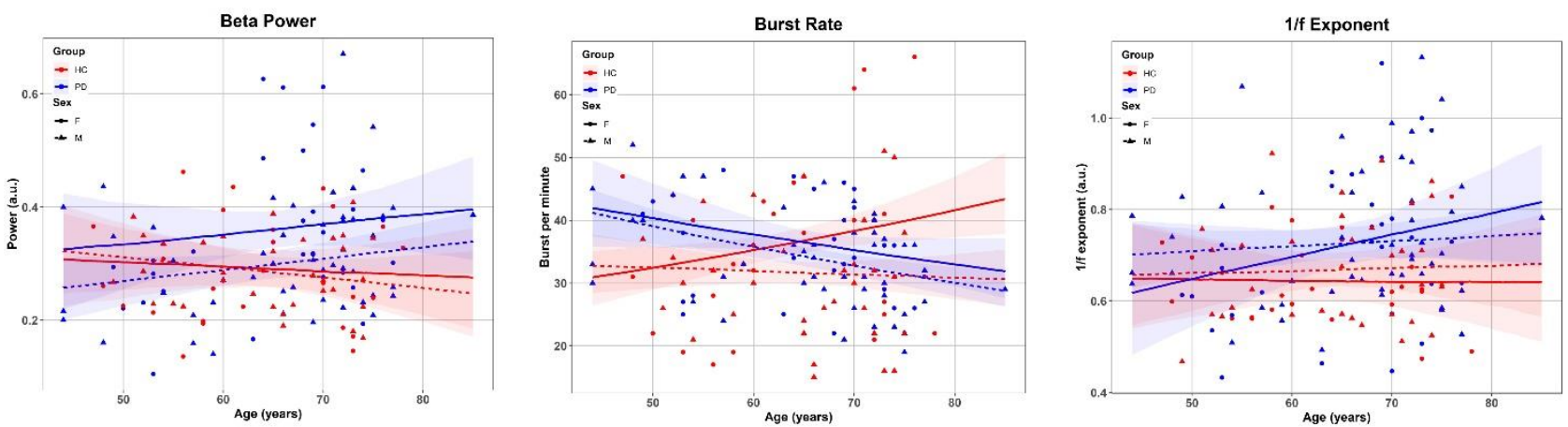

Figure 3: Scatterplots of the individual measures and model predictions over age for (A) PSD beta power, (B) burst rate, and (C) PSD broadband 1/f exponent, split between PD patients (blue) and healthy controls (red), and female (solid) and male (dashed).

\subsection{Clinical symptoms and sensorimotor oscillatory features}

The analysis of axial symptoms (midline function rating in MDS-UPDRS-III) showed a positive significant effect of median burst duration $\left(\chi^{2}(1)=5.00 ; p=0.025\right)$ and a marginally significant effect PSD beta power $\left(\chi^{2}(1)=3.86\right.$; $p=0.049)$ showing that longer burst duration and higher beta power was associated with an increase in midline function symptoms. In addition, there were significant effects of covariates age $\left(\chi^{2}(1)=7.12 ; p=0.005\right)$ and $\operatorname{sex}\left(\chi^{2}(1)=8.25 ; p=0.004\right)$ on midline function.

Upper limbs bradykinesia showed significant effects of burst rate $\left(\chi^{2}(1)=9.29 ; p=0.002\right)$ and alpha centre frequency $\left(\chi^{2}(1)=6.14 ; p=0.013\right)$ as well as a significant effect of the covariate cortical thickness $\left(\chi^{2}(1)=6.09\right.$; $p=0.014)$. The negative effect of burst rate means that reduced burst rate was associated with increased symptom rating.

There were no significant effects of the main predictors on symptom rating for rest tremor, rigidity, postural/kinetic tremor, nor lower limb bradykinesia, though there was a significant effect of sex on rest 
medRxiv preprint doi: https://doi.org/10.1101/2021.06.27.21259592; this version posted June 30, 2021. The copyright holder for this preprint (which was not certified by peer review) is the author/funder, who has granted medRxiv a license to display the preprint in perpetuity.

It is made available under a CC-BY 4.0 International license .

198 tremor $\left(\chi^{2}(1)=7.81 ; p=0.005\right)$. The standardised regression coefficients of each predictor variable on the 199 motor symptoms measured with MDS-UPDRS-III are presented in Table 4. 
medRxiv preprint doi: https://doi.org/10.1101/2021.06.27.21259592; this version posted June 30, 2021. The copyright holder for this preprint (which was not certified by peer review) is the author/funder, who has granted medRxiv a license to display the preprint in perpetuity.

It is made available under a CC-BY 4.0 International license .

\begin{tabular}{|c|c|c|c|c|c|c|c|}
\hline $\begin{array}{l}\text { Variable } \\
\text { category }\end{array}$ & Variable & $\begin{array}{l}\text { Midline } \\
\text { function }\end{array}$ & Rest tremor & Rigidity & $\begin{array}{l}\text { Bradykinesia } \\
\text { upper } \\
\text { extremity }\end{array}$ & $\begin{array}{l}\text { Postural and } \\
\text { kinetic } \\
\text { tremors }\end{array}$ & $\begin{array}{l}\text { Bradykinesia } \\
\text { lower limb }\end{array}$ \\
\hline & Intercept & -0.42 & -0.52 & -0.33 & 0.02 & -0.26 & 0.12 \\
\hline & & LL: -0.80 & LL: -0.93 & LL: -0.80 & LL: -0.40 & LL: -0.71 & LL: -0.71 \\
\hline & & UL: -0.04 & UL: -0.13 & UL: 0.13 & UL: 0.40 & UL: 0.16 & UL: 0.19 \\
\hline \multirow{18}{*}{ PSD } & Beta power & 0.33 & 0.24 & 0.33 & -0.18 & 0.00 & -0.22 \\
\hline & & LL: -0.06 & LL: -0.16 & LL: -0.12 & LL: -0.57 & LL: -0.41 & LL: -0.43 \\
\hline & & UL: 0.70 & UL: 0.64 & UL: 0.78 & UL: 0.17 & UL: 0.42 & UL: 0.44 \\
\hline & Beta centre & 0.02 & -0.20 & 0.03 & -0.11 & -0.13 & 0.01 \\
\hline & frequency & LL: -0.27 & LL: -0.50 & LL: -0.32 & LL: -0.38 & LL: -0.46 & LL: -0.45 \\
\hline & & UL: 0.30 & UL: 0.10 & UL: 0.36 & UL: 0.20 & UL: 0.20 & UL: 0.19 \\
\hline & Alpha & -0.11 & -0.22 & -0.12 & 0.24 & 0.11 & 0.02 \\
\hline & power & LL: -0.50 & LL: -0.61 & LL: -0.58 & LL: -0.14 & LL: -0.34 & LL: -0.34 \\
\hline & & UL: 0.28 & UL: 0.21 & UL: 0.35 & UL: 0.66 & UL: 0.57 & UL: 0.54 \\
\hline & Alpha & 0.01 & 0.13 & 0.12 & 0.29 & 0.08 & 0.22 \\
\hline & centre & LL: -0.24 & LL: -0.16 & LL: -0.16 & LL: 0.01 & LL: -0.21 & LL: -0.22 \\
\hline & frequency & UL: 0.24 & UL: 0.40 & UL: 0.43 & UL: 0.56 & UL: 0.38 & UL: 0.38 \\
\hline & $1 / f$ & -0.13 & 0.47 & 0.45 & -0.59 & 0.35 & -0.98 \\
\hline & intercept & LL: -1.11 & LL: -0.66 & LL: -0.86 & LL: -1.63 & LL: -0.84 & LL: -0.89 \\
\hline & & UL: 0.89 & UL: 1.54 & UL: 1.70 & UL: 0.42 & UL: 1.51 & UL: 1.50 \\
\hline & $1 / f$ & -0.05 & -0.26 & -0.16 & 0.17 & -0.02 & 0.46 \\
\hline & exponent & LL: -0.67 & LL: -0.87 & LL: -0.86 & LL: -0.47 & LL: -0.74 & LL: -0.73 \\
\hline & & UL: 0.56 & UL: 0.39 & UL: 0.63 & UL: 0.81 & UL: 0.70 & UL: 0.68 \\
\hline \multirow{12}{*}{ Burst } & Rate & 0.13 & 0.05 & 0.06 & -0.60 & -0.08 & 0.15 \\
\hline & & LL: -0.28 & LL: -0.40 & LL: -0.48 & LL: -1.01 & LL: -0.59 & LL: -0.57 \\
\hline & & UL: 0.56 & UL: 0.53 & UL: 0.61 & UL: -0.17 & UL: 0.43 & UL: 0.40 \\
\hline & Length & 0.31 & -0.15 & 0.07 & 0.09 & -0.07 & 0.27 \\
\hline & & LL: 0.00 & LL: -0.46 & LL: -0.32 & LL: -0.22 & LL: -0.42 & LL: -0.42 \\
\hline & & UL: 0.60 & UL: 0.16 & UL: 0.45 & UL: 0.42 & UL: 0.29 & UL: 0.29 \\
\hline & Interval & 0.29 & 0.12 & 0.18 & -0.21 & -0.01 & 0.35 \\
\hline & & LL: -0.07 & LL: -0.31 & LL: -0.31 & LL: -0.58 & LL: -0.44 & LL: -0.46 \\
\hline & & UL: 0.66 & UL: 0.55 & UL: 0.64 & UL: 0.20 & UL: 0.43 & UL: 0.44 \\
\hline & Amplitude & 0.04 & -0.19 & -0.30 & 0.67 & -0.15 & 0.64 \\
\hline & & LL: -0.83 & LL: -1.12 & LL: -1.34 & LL: -0.20 & LL: -1.10 & LL: -1.19 \\
\hline & & UL: 0.88 & UL: 0.72 & UL: 0.78 & UL: 1.59 & UL: 0.88 & UL: 0.84 \\
\hline \multirow{9}{*}{ Other } & Age & 0.03 & 0.00 & 0.00 & 0.01 & 0.01 & 0.01 \\
\hline & & LL: 0.01 & LL: -0.03 & LL: -0.03 & LL: -0.02 & LL: -0.02 & LL: -0.02 \\
\hline & & UL: 0.06 & UL: 0.03 & UL: 0.03 & UL: 0.04 & UL: 0.04 & UL: 0.04 \\
\hline & Sex & 0.70 & 0.74 & 0.55 & -0.14 & 0.33 & -0.25 \\
\hline & & LL: 0.17 & LL: 0.17 & LL: -0.04 & LL: -0.70 & LL: -0.31 & LL: -0.31 \\
\hline & & UL: 1.18 & UL: 1.32 & UL: 1.22 & UL: 0.45 & UL: 0.97 & UL: 0.94 \\
\hline & Cortical & -0.17 & -0.05 & -0.05 & -0.27 & -0.18 & -0.10 \\
\hline & thickness & LL: -0.41 & LL: -0.29 & LL: -0.34 & LL: -0.51 & LL: -0.48 & LL: -0.46 \\
\hline & & UL: 0.07 & UL: 0.22 & UL: 0.25 & UL: -0.03 & UL: 0.11 & UL: 0.11 \\
\hline & $\begin{array}{l}\text { Multiple } R- \\
\text { squared }\end{array}$ & 0.441 & 0.277 & 0.156 & 0.375 & 0.193 & 0.173 \\
\hline
\end{tabular}


medRxiv preprint doi: https://doi.org/10.1101/2021.06.27.21259592; this version posted June 30, 2021. The copyright holder for this preprint (which was not certified by peer review) is the author/funder, who has granted medRxiv a license to display the preprint in perpetuity.

It is made available under a CC-BY 4.0 International license .

203

204

205

206

207

208

209

210

211

212

213

214

215

216

217

218

\subsection{Correlation between variables}

Table 5 presents the significant correlations between the PSD summaries, burst features, age, cortical thickness and clinical rating scales. There was generally high correlations between the PSD features and burst features.

The PSD beta power correlated with the burst rate $(r=0.26, p=0.002)$, burst duration $(r=0.20, p=0.022)$, burst

amplitude $(r=0.52, p<0.001)$, and correlated negatively with the burst interval $(r=-0.24, p=0.005)$. The PSD alpha power also correlated with the burst rate $(r=0.26 p<0.001)$, burst amplitude $(r=0.32, p<0.001)$ and showed a negative correlation with the bursts interval $(r=-0.23, p=0.011)$. The PSD centre frequencies in neither the betaband nor alpha-bad showed any significant correlation with burst features.

The $1 / \mathrm{f}$ broadband characteristic of the PSD showed high degree of correlation with the measures of the oscillatory peaks in the PSD for both the $1 / f$ intercept (beta power: $r=0.52, p<0.001$; beta centre frequency: $r=-$ $0.18, p=0.035$; alpha power: $r=0.41, p<0.001$; alpha centre frequency: $r=-0.19, p=0.035)$ and $1 / f$ exponent (beta power: $r=0.57, p<0.001$; beta centre frequency: $r=-0.30, p<0.001$; alpha power: $r=0.40, p<0.001$; , alpha centre frequency: $r=-0.43, p<0.001)$. The $1 / f$ intercept further showed a high degree of correlation with all four burst features (burst rate: $r=0.55, p<0.001$; burst duration: $r=0.31, p<0.001$; bursts interval: $r=-0.48 . p<0.001$; burst amplitude: $r=0.91, p<0.001)$, though the $1 / f$ exponent only correlated with the burst amplitude $(r=0.30$, $p<0.001$ ). 
medRxiv preprint doi: https://doi.org/10.1101/2021.06.27.21259592; this version posted June 30, 2021. The copyright holder for this preprint (which was not certified by peer review) is the author/funder, who has granted medRxiv a license to display the preprint in perpetuity.

It is made available under a CC-BY 4.0 International license .

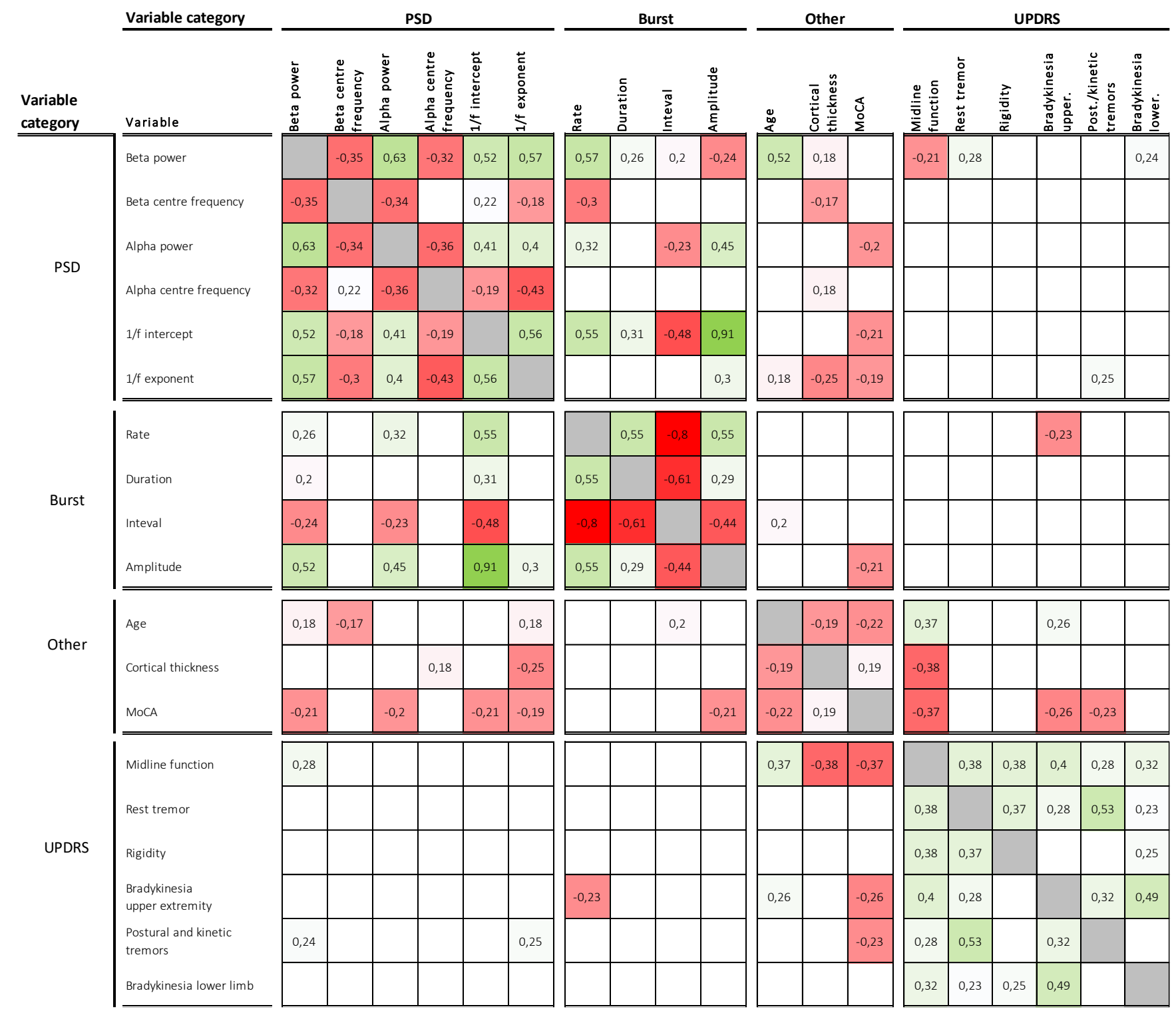


medRxiv preprint doi: https://doi.org/10.1101/2021.06.27.21259592; this version posted June 30, 2021. The copyright holder for this preprint (which was not certified by peer review) is the author/funder, who has granted medRxiv a license to display the preprint in perpetuity.

It is made available under a CC-BY 4.0 International license .

224

In this study, we aimed to explore how different features of somatosensory oscillatory neuronal activity differed between PD patients and healthy controls across age and gender, and how these features relate to motor symptoms in PD. In agreement with our primary hypothesis, the PD patients differed from healthy controls on several oscillatory features as expected, showing higher beta-band power, higher burst amplitude, a steeper broadband $1 / \mathrm{f}$ slope and exponent compared to healthy controls. Furthermore, the analysis of bursts showed that the burst rate was reduced in PD patients compared to healthy controls, confirming previous results on bursts and PD from our group ${ }^{17}$-here on a cohort with three times as many participants. Notably, our current results show that the reduced burst rate in PD is not a static group-level difference but interacts with age, gender and cortical thickness and results in a steeper reduction in burst rate in PD with age compared to healthy controls.

Following our secondary hypothesis, we expected that different oscillatory features would reflect distinct underlying functional neural properties and manifest as different motor symptoms in PD. Examining the interrelationship between the features, we observed significant correlations between most oscillatory features, indicating that we had some redundancy among our measures. For instance, the $1 / \mathrm{f}$ intercept showed a significant positive correlation with the $1 / \mathrm{f}$ slope and beta-band PSD and a high correlation with burst amplitude. We did, however, also see evidence of independent features. Using regression models to examine which oscillatory features were associated with different symptoms, our results showed that the oscillatory features had distinctive relationships with specific symptom scales: bradykinesia severity was related to the burst rate, and alpha centre frequency (and also to cortical thickness) but midline symptoms were related to burst duration and beta power.

While we did see correlations between the band-specific oscillatory power in the PSD and the burst rate and burst amplitude-as expected since increased rate and amplitude would necessarily lead to higher PSD-it was, unexpectedly, the intercept of the broadband $1 /$ f regression that showed the highest correlation with the 
medRxiv preprint doi: https://doi.org/10.1101/2021.06.27.21259592; this version posted June 30, 2021. The copyright holder for this preprint (which was not certified by peer review) is the author/funder, who has granted medRxiv a license to display the preprint in perpetuity.

It is made available under a CC-BY 4.0 International license.

burst features. This study adds to the growing evidence that a narrow-band focus-e.g. the beta-band in isolation-could potentially miss essential aspects of the neural signals. Quantifying only the peaks in the PSD misrepresents the actual oscillatory response at those frequencies as the peaks are influenced by the broadband offset and 1/f decay exponent, so any unaccounted-for systematic differences in either PSD offset or decay exponent can lead to a false conclusion that there is a difference in the oscillatory response. ${ }^{46,47}$

These results show that the different features capture different neural processes, reflecting that a neural time series obtained by electrophysiological recordings differs along various dimensions. In the time domain, increased oscillatory power can reflect both increased burst duration and change in burst amplitude and an expression of "true" sustained oscillations in the signal. ${ }^{34,51}$ The presence of more sustained oscillation in the sensorimotor rhythm, particularly the beta band, might reflect a higher level of inhibition of sensorimotor information as is seen in recordings from STN ${ }^{5}$ and, to some extent, at the cortical level. ${ }^{36,52}$ However, sustained oscillations are not in contrast to the bursting properties of the sensorimotor rhythm. The neural time-series can express both a degree of sustained oscillations while also exhibiting variation in the degree of transient bursts -e.g. a signal of steady oscillation with transient high-amplitude bursts.

The observed disease-related changes in spontaneous cortical bursts in the form of increased burst power and a more rapid decrease in rate over age for PD patients could reflect inhibited projections along the thalamiccortical pathways caused by disturbances in the dopamine-dependent structures projecting to the cortex. The bursting properties of the cortical sensorimotor neural activity are proposed to occur due to long-range input through the ascending thalamic-cortical connection to the cortex, leading to an increase in the local neural excitation and resulting in a burst of synchronous activity. ${ }^{34}$ Interestingly, we did not find significant group differences in burst duration in the current study, supporting the view that the central mechanisms of the cortical bursts are not primarily affected in PD. The sub-cortical beta-band activity is directly influenced by the activity of dopamine-responding neurons, as there is a high density of dopamine-dependent neurons in these 
medRxiv preprint doi: https://doi.org/10.1101/2021.06.27.21259592; this version posted June 30, 2021. The copyright holder for this preprint (which was not certified by peer review) is the author/funder, who has granted medRxiv a license to display the preprint in perpetuity.

It is made available under a CC-BY 4.0 International license .

subcortical brain structures in contrast to the cortex, where the density of dopamine-receptive neurons is low. Any effect of dopamine and dopaminergic medication on the cortical beta-band is likely an indirect effect mediated by neural connectivity in the direct and indirect neural pathways between basal ganglia, thalamus, and cortex. The differences in the cortical sensorimotor burst rate in PD might be an indirect effect of the loss of dopamine and changes in the beta band in the sub-cortical structures projecting to the sensorimotor cortex. The notion that the cortical sensorimotor activity is indirectly related to dopamine depletion in PD is further supported by findings from animals studies showing that hydroxydopamine injections lead to exaggerated beta-band oscillations only after several days had passed, suggesting that oscillatory changes occurred as an effect after dopamine depletion rather than a direct consequence of the depletion itself. ${ }^{7}$ The indirect influence of dopamine on the cortical beta-band might also explain the often weak or even absent effect of dopaminergic medication on cortical beta-band activity. ${ }^{11,16,17,53}$ However, the current study cannot directly address the role of dopamine on cortical oscillations since all patients in the study were tested on their regular dose of medication.

We explored how age-related differences in cortical sensorimotor neural activity might interact with diseaserelated changes in PD within the current study. Age-related effects on spontaneous sensorimotor activity are commonly dealt with by matching the age distributions of the patient group and the healthy control groupusually within a narrow age span. The analysis showed, as expected, age-related differences in the sensorimotor activity-most notably in the beta PSD and for the burst duration, burst interval, and burst rate. The age-related differences in burst rate differed between PD patients and healthy controls, with PD patients showing a more considerable reduction of burst as a function of age than healthy controls. The steeper reduction in burst rate with age in PD seems in accordance with the fact that higher age at PD onset is associated with a faster disease progression and more rapid decline in motor function ${ }^{54}$, though a longitudinal design is needed to confirm the relation between disease progression, reduction in burst rate, and age. 
medRxiv preprint doi: https://doi.org/10.1101/2021.06.27.21259592; this version posted June 30, 2021. The copyright holder for this preprint (which was not certified by peer review) is the author/funder, who has granted medRxiv a license to display the preprint in perpetuity.

It is made available under a CC-BY 4.0 International license .

We did not see a significant "slowing" of the beta PSD centre frequency between groups, as reported in several previous studies..$^{43}$ An explanation might be that such slowing is more pronounced in PD patients with dementia ${ }^{26-29}$ and correlates with cognitive ability. ${ }^{25}$ The PD patients in the current study were cognitively wellfunctioning and did not differ in their cognitive ability from the healthy controls. Another explanation is that we focused on the activity in the sensorimotor cortex, whereas the slowing of alpha and beta PSD is usually found in frontal areas and globally throughout the brain. ${ }^{24,27,30}$

We included measures of cortical thickness within the same region of interest (ROI) from which we extracted the function time-series, as we hypothesised that age-related effects upon the functional measures might be mediated through the age-related structural changes in the cortex. However, despite the negative correlation between age and cortical thickness (as expected), we did not find pervasive evidence that cortical thickness affected the functional measures. Cortical thickness did show an effect on the burst rate through interaction on the age-related effect. The only measure that showed a group-specific difference in cortical thickness was the alpha centre frequency, where a higher cortical thickness was associated with a lower alpha PSD peak.

We also included sex to explore if disease-related changes in sensorimotor oscillatory activity differed between males and females, as there are well-documented sex differences in the manifestation of PD., ${ }^{1,55}$ Male sex is a risk factor for developing PD, with average incidence ratios of approximately 2:1 male-female ratio across all stages of the disease. ${ }^{56}$ The disease debuts on average two years earlier in males than females and differs in the initial manifestation of symptoms, with women more likely to develop tremor specific symptoms and men more likely to develop rigidity. ${ }^{57}$ We are not aware of any previous studies that explicitly included sex as a factor in analysing neural oscillations in PD.

We found significant differences between males and females in the bursting properties in the sensorimotor signal. The burst amplitude was more prominent for female PD patients than for male PD patients, and the age-related differences in both burst rate and burst intervals differed between males and females. These 
medRxiv preprint doi: https://doi.org/10.1101/2021.06.27.21259592; this version posted June 30, 2021. The copyright holder for this preprint (which was not certified by peer review) is the author/funder, who has granted medRxiv a license to display the preprint in perpetuity.

It is made available under a CC-BY 4.0 International license.

finding clearly illustrate the need for further studies into the sex-specific changes in neural function and how they manifest and relate to PD.

A possible factor behind the sex differences in PD is the contribution of sex hormones on the nigrostriatal pathway and linked to the deterioration of the dopaminergic system, where testosterone levels appear to enhance dopamine loss while estrogen has been identified as a neuroprotective agent for PD. Estrogen has been demonstrated by how it generally influences incidence levels and how menopause-related variations in estrogen levels are linked to variations in symptom severity. ${ }^{58}$ If this influences oscillations in the sensorimotor cortex is unclear at the current stage.

\section{4}

The present study quantified the neural time series from the sensorimotor cortex based on pre-defined summary measures of the PSD and burst properties. Our study is a broader approach with more sensorimotor rhythm features than other studies more focused on specific signal features, and we also included more PD patients and healthy controls than similar functional studies. ${ }^{43}$

However, focusing the analysis on different features within a narrow ROI potentially ignores other types of measurements that might be relevant to understanding the development of PD and motor symptoms; for example, the long-range connectivity between the sensorimotor cortex and other cortical areas and the connections between the sensorimotor cortex and the basal ganglia and thalamus (though the subcortical structures are practically invisible in MEG). Treating the activity in the sensorimotor cortex as single time series also means that we remove the sensitivity to spatial features of the signals, e.g. focal versus spatially blurred activity in one group or the other. If the oscillatory activity extends over a larger cortical surface area, then that signal will also manifest as power differences in the measured signal. ${ }^{51}$ There are potentially many more features to be uncovered, and future studies may explore how the PSD- and burst features further interact with other aspects of brain activity in the global function of the brain to fully understand the interaction 
medRxiv preprint doi: https://doi.org/10.1101/2021.06.27.21259592; this version posted June 30, 2021. The copyright holder for this preprint (which was not certified by peer review) is the author/funder, who has granted medRxiv a license to display the preprint in perpetuity.

It is made available under a CC-BY 4.0 International license .

339 We investigated a relatively large cohort of PD patients and healthy controls (for a neuroimaging study) to

340 make meaningful inferences about how age and sex interact with the group level difference between PD

341 patients and healthy controls, but a limitation is that our study is cross-sectional. We aim to follow this cohort

342 longitudinally to estimate the development trajectories of the sensorimotor oscillatory activity in PD compared

343 to healthy ageing.

344 There are myriads of ways to quantify brain dynamics, and finding features of neural signals that can explain

345 disease mechanism or symptoms, even if extracted along with a reduced number of dimensions, will be helpful

346 if they provide adequate information about the disease- or symptom-state. Further characterisation of the

347 association between features in the non-invasive brain signals and motor symptoms can potentially be a

348 valuable tool to aid in the diagnosis and evaluation of treatments. Understanding how features in the neural

349 time series are related to motor symptoms in PD will also help develop non-invasive neural stimulation that can

350 potentially relieve motor symptoms..$^{35,59}$ 
medRxiv preprint doi: https://doi.org/10.1101/2021.06.27.21259592; this version posted June 30, 2021. The copyright holder for this preprint (which was not certified by peer review) is the author/funder, who has granted medRxiv a license to display the preprint in perpetuity.

It is made available under a CC-BY 4.0 International license.

351

352

353

354

355

356

357

358

359

360

361

362

363

364

365

366

367

368

369

370

371

\section{Methods}

\subsection{Participants}

80 PD patients (age 44-85; 32 female) and 71 healthy controls (age 46-78; 46 female) participated in the study.

The study was approved by the regional ethics committee (Etikprövningsnämden Stockholm, DNR 2019-00542) and followed the Declaration of Helsinki. All participants gave written informed consent before participation.

The PD patients were recruited from the Parkinson's Outpatient Clinic, Department of Neurology, Karolinska

University Hospital, Stockholm, Sweden. The healthy controls were recruited by advertising or amongst spouses of PD patients. 22 participants (18 patients, 4 healthy controls) were included from a previous study ${ }^{17}$ who were qualified based on the recruitment criteria of the present study and had done the same MEG and MRI procedures as in the present study. All data were reanalysed following the procedure described below.

The inclusion criteria for the PD group were a diagnosis of PD according to the United Kingdom Parkinson's Disease Society Brain Bank Diagnostic Criteria with Hoehn and Yahr stage 1-3. ${ }^{60}$ Inclusion criteria for the control group were not having a diagnosis of PD, no form of movement disorder, and no history of neurological disorders, epilepsy, or psychiatric disorders.

Exclusion criteria for both groups were a diagnosis of major depression, dementia, history or presence of schizophrenia, bipolar disorder, epilepsy, or history of alcoholism or drug addiction according to the Diagnostic and Statistical Manual of Mental Disorders. ${ }^{61}$

One participant declined to do the MRI scanning, one participant had a scanner malfunction during MRI acquisition, and eleven participants had their MRI scans cancelled and were not included in the analysis. Twp PD patients and 11 healthy controls were excluded. Table 1 is a summary of the participants included in the analysis. 
medRxiv preprint doi: https://doi.org/10.1101/2021.06.27.21259592; this version posted June 30, 2021. The copyright holder for this preprint (which was not certified by peer review) is the author/funder, who has granted medRxiv a license to display the preprint in perpetuity.

It is made available under a CC-BY 4.0 International license .

372 The PD patients participated in the study while they were on their regular prescribed dose of medication. The

373 Levodopa equivalent daily dose (LEDD) was calculated according to Tomlinson et al. ${ }^{62}$ Motor symptoms in the

374 PD group were assessed using the Movement-Disorder Society Unified Parkinson's Disease Rating Scale (MDS-

375 UPDRS-III)..$^{59}$ Global cognition was assessed with the Montreal Cognitive Assessment battery (MoCA). ${ }^{64}$

376

377

378

379

380

381

382

383

384

385

386

387

388

\subsection{MEG recordings}

MEG data were recorded with a Neuromag TRIUX 306-channel MEG system, with 102 magnetometers and 102 pairs of planar gradiometers. Data were sampled at $1000 \mathrm{~Hz}$ with an online $0.1 \mathrm{~Hz}$ high-pass filter and $330 \mathrm{~Hz}$ low-pass filter. The MEG scanner was located inside a two-layer magnetically shielded room (Vacuumschmelze $\mathrm{GmbH}$ ) with internal active shielding active to suppress electromagnetic artefacts. The subjects' head position and head movements inside the MEG scanner were measured during recordings with head-position indicator coils (HPI) attached to subjects' heads. The HPI location and additional points sampled uniformly across the subjects' head shape were digitalised with a Polhemus Fastrak motion tracker before the measurements. Horizontal and vertical electrooculogram (EOG) and electrocardiogram (ECG) were recorded simultaneously with the MEG.

We recorded three minutes of resting-state MEG while the participants sat with their eyes closed. The participants were instructed to close their eyes and relax for three minutes. The recordings began after assuring the participant sat still with their eyes closed.

\subsection{MRI acquisition}

3D T1-weighted magnetisation-prepared rapid gradient-echo (MPRAGE) sequence structural images (voxel size: $1 \times 0.94 \times 0.94 \mathrm{~mm}$ ) were obtained on a GE Discovery 3.0 T MR scanner for morphological analysis and creating source spaces for MEG source reconstruction. Multi-echo "FLASH"65 images were obtained to create volumetric headmodels for MEG source reconstruction (see below). 
medRxiv preprint doi: https://doi.org/10.1101/2021.06.27.21259592; this version posted June 30, 2021. The copyright holder for this preprint (which was not certified by peer review) is the author/funder, who has granted medRxiv a license to display the preprint in perpetuity.

It is made available under a CC-BY 4.0 International license .

394

395

396

397

398

399

400

401

402

403

404

405

406

407

408

409

410

411

412

413

414

415

\subsection{MRI processing}

The MRI images were processed with Freesurfer ${ }^{66}$ (v. 5.3) to get surface reconstructions of the cortical mantle. The surfaces were obtained with the automatic routine for extracting cortical surfaces in Freesurfer from the individual T1-weighted MRI.

We defined the cortical sensorimotor area by segmenting the cortical surface using the anatomical labels provided by Freesurfer automatic labelling. ${ }^{67}$ The analysis focused on a region of interest (ROI) consisting of the left pre- and post-central gyri and central sulcus. The pre/postcentral gyri were combined because a biomagnetic source on either sulci wall will leave a trance on the other side due to the close distance and the field spread of MEG signals. The ROI was defined for each subject based on the individual cortical reconstructions. The average cortical thickness in the ROI was estimated with Freesurfer. ${ }^{68}$

\subsection{MEG pre-processing}

The MEG was processed by applying temporal signal space separation (tSSS) to suppress artefacts from outside the scanner helmet and correct head movement during the recording. ${ }^{69}$ The tSSS had a buffer length of $10 \mathrm{~s}$ and a cut-off correlation coefficient of 0.95 . Movement correction was done by shifting the head position to a position based on the median of the continuous head position during the three-minute recording.

The MEG data processing and source reconstruction was done with MNE-Python ${ }^{70}$ in Python 3.8. First, we marked data segments containing muscle artefacts and SQUID jumps (marked by the automatic artefact detection in MNE-Python). The data was filtered with a $48 \mathrm{~Hz}$ low-pass filter and $50 \mathrm{~Hz}$ notch filter to remove line noise. The continuous data were cut into $1.0 \mathrm{~s}$ epochs. Epochs marked with muscle artefacts or extreme values (above $5000 \mathrm{fT}$ for magnetometers and $4000 \mathrm{fT} / \mathrm{cm}$ for gradiometers) were rejected. Between 0-65 \% (median: $6.0 \%$ ) of data was rejected resulting in 63.0-180 s (median: $174.0 \mathrm{~s}$ ) useful MEG data per participant. The remaining data length was not significantly different between groups (Wilcoxon rank sum test, $p=0.98$ ). 
medRxiv preprint doi: https://doi.org/10.1101/2021.06.27.21259592; this version posted June 30, 2021. The copyright holder for this preprint (which was not certified by peer review) is the author/funder, who has granted medRxiv a license to display the preprint in perpetuity.

It is made available under a CC-BY 4.0 International license .

416 We then used independent component analysis (ICA) using the fastica algorithm. ${ }^{71}$ Components representing

417 artefacts from blinks and heartbeats were identified based on their correlation with the EOG and ECG,

418 respectively and removed from the raw data. Between 0-5 (median 3) components were removed per

419 participant. The number of removed ICA components was not significantly different between groups (Wilcoxon

420 rank sum test, $p=0.71$.

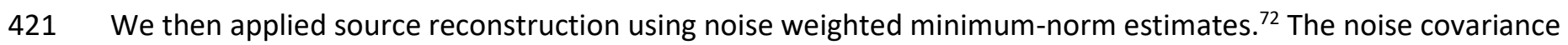

422 matrix was estimated from two minutes of empty room data recorded before each session. The source space

423 consisted of 5124 evenly spaced points sampled across the white matter surfaces per participant. The inner

424 skull boundary was estimated from the multi-echo MRI to create a single shell volume conductor model. The

425 time series from the sensorimotor ROI was then extracted from the estimated source time series by singular

426 value decomposition of all source points within the ROI.

\section{$427 \quad 4.6$ Power spectral analysis}

428 We analysed the spectral properties of the sensorimotor activity by calculating the PSD from 0.5 to $40 \mathrm{~Hz}$

429 across the entire ROI time series using Welch's method by segmenting the continuous data into $3.072 \mathrm{~s}$ epochs

430 with $50 \%$ overlap and averaging the PSD across the segments.

431 Since the narrow-band beta power in the PSD is dependent on the broader features of the broadband

432

spectrum, we further analysed the $1 / \mathrm{f}$ broadband characterises of the sensorimotor activity as this could play a

role in the functional properties of the beta-band and has been shown to differ between healthy control and

434 PD patients. ${ }^{17}$ We used the fitting oscillations \& one over $f$ (FOOOF) toolbox ${ }^{46}$ to analyse the $1 / \mathrm{f}$ broadband

435 characteristic of the PSD (intercept and exponent) and the oscillatory peaks in the canonically defined beta

436 band $(13-30 \mathrm{~Hz})$ and alpha band $(8-12 \mathrm{~Hz})$. A log-linear regression is fitted to the PSD and subtracted before

437 fitting Gaussian functions to the peaks in the PSD. The midpoint of the Gaussians corresponds to the centre 
medRxiv preprint doi: https://doi.org/10.1101/2021.06.27.21259592; this version posted June 30, 2021. The copyright holder for this preprint (which was not certified by peer review) is the author/funder, who has granted medRxiv a license to display the preprint in perpetuity.

It is made available under a CC-BY 4.0 International license .

438 frequency (i.e. peak frequency) and the height represents the signal power. A new log-linear function is fitted

439 to the PSD after substracting the Gaussian function to estimate the $1 / \mathrm{f}$ characteristic.

440 All participants showed a discernable beta peak in the PSD. Nine PD patients and nine healthy controls did not

441 show a peak in the PSD alpha band (no difference between groups, $\chi^{2}(1)=0.12 ; p=0.73$ ).

\section{$442 \quad 4.7$ Burst analysis}

443 To calculate the burst properties of the sensorimotor activity in the time domain, we band-pass filtered the

444 time-series with an 8-30 Hz band-pass filter using FieldTrip ${ }^{73}$ in MATLAB (R2016b; MathWorks Inc.) and

445 calculated the Hilbert envelope of the signal (Fig. 1). The burst threshold was defined as three times the

446 median of the signal. The burst onset was defined as the time-point where the signal first reached half the max

447 amplitude of the burst and ending at the time-point where the signal again dropped below half the max

448 amplitude of the burst. The burst amplitude was defined as the maximum value of the burst. The burst

449 duration was defined as the time from burst onset to burst end. The burst interval was defined as the time

450 from the end of a burst to the time-point where the next burst began.

\subsection{Statistics}

452

\subsubsection{Analysis of sensorimotor rhythm features}

453 The main analyses tested the effect of group (PD patients/healthy controls), age, sex, and ROI cortical thickness

on the features listed in Table 2 to describe how these factors might influence the features. For the PSD

features, we modelled the outcomes as a linear function of group (PD patients/healthy controls), age, sex, and

cortical thickness with linear regression in $R\left(v\right.$. 4.0.2).$^{74}$ The regression models were fit to the data for each 
medRxiv preprint doi: https://doi.org/10.1101/2021.06.27.21259592; this version posted June 30, 2021. The copyright holder for this preprint (which was not certified by peer review) is the author/funder, who has granted medRxiv a license to display the preprint in perpetuity.

It is made available under a CC-BY 4.0 International license.

\subsubsection{Relation between clinical scores and sensorimotor oscillatory features}

461 The MDS-UPDRS-III scores were divided into subscales based on symptoms: midline function, rest tremor,

rigidity, upper-body bradykinesia, postural and kinetic tremor, and lower limb bradykinesia; according to Goetz

et al. ${ }^{75}$, with the exception that left- and right-side upper-body bradykinesia were combined into a single factor.

Each symptom score was analysed by multiple regression and modelled as a function of the burst rate, median

burst duration, median bursts interval, median burst amplitude, PSD 1/f intercept, PSD 1/f exponent, PSD beta

power, PSD beta centre frequency, PSD alpha power, and PSD alpha centre frequency for each PD patient. The

models further included the age, sex, and cortical thickness to regress out the contribution hereof and estimate

the relative effect size of each signal feature. All symptom ratings and continuous predictor variables, except

age, were z-transformed to get the standardised effect size from the regression models. Significance testing

was done by removing one predictor from the model and comparing the variance explained between the full

471 model and the model with a predictor removed by log-likelihood ratio tests.

\subsubsection{Correlation between variables}

473 Since the features analysed in the main analysis are all extracted from the same signal, we wanted to explore

474 the mutual relation between variables. We computed the Pearson correlation between the signal features in

475 Table 2, age, cortical thickness, MoCA, and MDS-UPDRS-IIl subscales for all pairwise complete cases.

\subsection{Data Availability}

477 Parts of the data used in this analysis will be made available at a public data repository. Scripts for running the 
medRxiv preprint doi: https://doi.org/10.1101/2021.06.27.21259592; this version posted June 30, 2021. The copyright holder for this preprint (which was not certified by peer review) is the author/funder, who has granted medRxiv a license to display the preprint in perpetuity.

It is made available under a CC-BY 4.0 International license .

479

480

481

482

483

484

485

486

487

488

489

490

491

492

493

494

495

496

497

498

499

500

501

\section{References}

1. Kalia, L. V. \& Lang, A. E. Parkinson's disease. The Lancet 386, 896-912 (2015).

2. Rodriguez-Oroz, M. C. et al. Initial clinical manifestations of Parkinson's disease: features and pathophysiological mechanisms. The Lancet Neurology 8, 1128-1139 (2009).

3. Braak, H. et al. Staging of brain pathology related to sporadic Parkinson's disease. Neurobiology of aging 24, 197-211 (2003).

4. Jenkinson, N. \& Brown, P. New insights into the relationship between dopamine, beta oscillations and motor function. Trends in Neurosciences 34, 611-618 (2011).

5. Alonso-Frech, F. et al. Slow oscillatory activity and levodopa-induced dyskinesias in Parkinson's disease. Brain 129, 1748-1757 (2006).

6. Giannicola, G. et al. The effects of levodopa and ongoing deep brain stimulation on subthalamic beta oscillations in Parkinson's disease. Experimental Neurology 226, 120-127 (2010).

7. Mallet, N. et al. Disrupted Dopamine Transmission and the Emergence of Exaggerated Beta Oscillations in Subthalamic Nucleus and Cerebral Cortex. Journal of Neuroscience 28, 4795-4806 (2008).

8. Neumann, W.-J. et al. Long term correlation of subthalamic beta band activity with motor impairment in patients with Parkinson's disease. Clinical Neurophysiology 128, 2286-2291 (2017).

9. Kühn, A. A., Kupsch, A., Schneider, G.-H. \& Brown, P. Reduction in subthalamic 8-35 Hz oscillatory activity correlates with clinical improvement in Parkinson's disease: STN activity and motor improvement.

European Journal of Neuroscience 23, 1956-1960 (2006).

10. Martin, S. et al. Differential contributions of subthalamic beta rhythms and $1 / \mathrm{f}$ broadband activity to motor symptoms in Parkinson's disease. npj Parkinson's Disease 4, 32 (2018).

11. Airaksinen, K. et al. Somatomotor mu rhythm amplitude correlates with rigidity during deep brain stimulation in Parkinsonian patients. Clinical Neurophysiology 123, 2010-2017 (2012). 
medRxiv preprint doi: https://doi.org/10.1101/2021.06.27.21259592; this version posted June 30, 2021. The copyright holder for this preprint (which was not certified by peer review) is the author/funder, who has granted medRxiv a license to display the preprint in perpetuity.

It is made available under a CC-BY 4.0 International license .

502

503

504

505

506

507

508

509

510

511

512

513

514

515

516

517

518

519

520

521

522

523

524

12. Feldmann, L. K. et al. Subthalamic beta band suppression reflects effective neuromodulation in chronic recordings. European Journal of Neurology ene.14801 (2021) doi:10.1111/ene.14801.

13. Cao, C. et al. L-dopa treatment increases oscillatory power in the motor cortex of Parkinson's disease patients. Neurolmage: Clinical 26, 102255 (2020).

14. Heinrichs-Graham, E. et al. Hypersynchrony despite pathologically reduced beta oscillations in patients with Parkinson's disease: a pharmaco-magnetoencephalography study. Journal of Neurophysiology 112, 1739-1747 (2014).

15. Melgari, J.-M. et al. Alpha and beta EEG power reflects L-dopa acute administration in parkinsonian patients. Frontiers in Aging Neuroscience 6, 302 (2014).

16. Hall, S. D. et al. GABA-mediated changes in inter-hemispheric beta frequency activity in early-stage Parkinson's disease. Neuroscience 281, 68-76 (2014).

17. Vinding, M. C. et al. Reduction of spontaneous cortical beta bursts in Parkinson's disease is linked to symptom severity. Brain Communications (2020) doi:10.1093/braincomms/fcaa052.

18. Abbasi, O. et al. Unilateral deep brain stimulation suppresses alpha and beta oscillations in sensorimotor cortices. Neurolmage 174, 201-207 (2018).

19. Luoma, J. et al. Spontaneous sensorimotor cortical activity is suppressed by deep brain stimulation in patients with advanced Parkinson's disease. Neuroscience Letters 683, 48-53 (2018).

20. Cao, C.-Y. et al. Modulations on cortical oscillations by subthalamic deep brain stimulation in patients with Parkinson disease: A MEG study. Neuroscience Letters 636, 95-100 (2017).

21. Pollok, B. et al. Motor-cortical oscillations in early stages of Parkinson's disease: Suppression of motor cortical beta oscillations is altered in early PD. The Journal of Physiology 590, 3203-3212 (2012).

22. Olde Dubbelink, K. T. E. et al. Resting-state functional connectivity as a marker of disease progression in Parkinson's disease: A longitudinal MEG study. Neurolmage: Clinical 2, 612-619 (2013). 
medRxiv preprint doi: https://doi.org/10.1101/2021.06.27.21259592; this version posted June 30, 2021. The copyright holder for this preprint (which was not certified by peer review) is the author/funder, who has granted medRxiv a license to display the preprint in perpetuity.

It is made available under a CC-BY 4.0 International license .

23. Boon, L. I. et al. Motor effects of deep brain stimulation correlate with increased functional connectivity in Parkinson's disease: An MEG study. Neurolmage: Clinical 26, 102225 (2020).

24. Stoffers, D. et al. Slowing of oscillatory brain activity is a stable characteristic of Parkinson's disease without dementia. Brain 130, 1847-1860 (2007).

25. Vardy, A. N. et al. Slowing of M1 activity in Parkinson's disease during rest and movement - An MEG study. Clinical Neurophysiology 122, 789-795 (2011).

26. Bosboom, J. L. W., Stoffers, D., Wolters, E. Ch., Stam, C. J. \& Berendse, H. W. MEG resting state functional connectivity in Parkinson's disease related dementia. Journal of Neural Transmission 116, 193-202 (2009).

27. Bosboom, J. L. W. et al. Resting state oscillatory brain dynamics in Parkinson's disease: An MEG study. Clinical Neurophysiology 117, 2521-2531 (2006).

28. Olde Dubbelink, K. T. E. et al. Predicting dementia in Parkinson disease by combining neurophysiologic and cognitive markers. Neurology 82, 263-270 (2014).

29. Ponsen, M. M., Stam, C. J., Bosboom, J. L. W., Berendse, H. W. \& Hillebrand, A. A three dimensional anatomical view of oscillatory resting-state activity and functional connectivity in Parkinson's disease related dementia: An MEG study using atlas-based beamforming. Neurolmage: Clinical 2, 95-102 (2013).

30. Olde Dubbelink, K. T. E. et al. Cognitive decline in Parkinson's disease is associated with slowing of restingstate brain activity: a longitudinal study. Neurobiology of Aging 34, 408-418 (2013).

31. Stoffers, D., Bosboom, J. L. W., Wolters, E. Ch., Stam, C. J. \& Berendse, H. W. Dopaminergic modulation of cortico-cortical functional connectivity in Parkinson's disease: An MEG study. Experimental Neurology 213, 191-195 (2008).

32. Feingold, J., Gibson, D. J., DePasquale, B. \& Graybiel, A. M. Bursts of beta oscillation differentiate postperformance activity in the striatum and motor cortex of monkeys performing movement tasks. Proc Natl Acad Sci USA 112, 13687-13692 (2015). 
medRxiv preprint doi: https://doi.org/10.1101/2021.06.27.21259592; this version posted June 30, 2021. The copyright holder for this preprint (which was not certified by peer review) is the author/funder, who has granted medRxiv a license to display the preprint in perpetuity.

It is made available under a CC-BY 4.0 International license .

548

549

550

551

552

553

554

555

556

557

558

559

560

561

562

563

564

565

566

567

568

569

570

571

33. Leventhal, D. K. et al. Basal Ganglia Beta Oscillations Accompany Cue Utilization. Neuron 73, 523-536 (2012).

34. Sherman, M. A. et al. Neural mechanisms of transient neocortical beta rhythms: Converging evidence from humans, computational modeling, monkeys, and mice. Proceedings of the National Academy of Sciences 113, E4885-E4894 (2016).

35. Tinkhauser, G. et al. The modulatory effect of adaptive deep brain stimulation on beta bursts in Parkinson's disease. Brain 140, 1053-1067 (2017).

36. Shin, H., Law, R., Tsutsui, S., Moore, C. I. \& Jones, S. R. The rate of transient beta frequency events predicts behavior across tasks and species. elife 6, (2017).

37. Duchet, B. et al. Average beta burst duration profiles provide a signature of dynamical changes between the ON and OFF medication states in Parkinson's disease. http://biorxiv.org/lookup/doi/10.1101/2020.04.27.064246 (2020) doi:10.1101/2020.04.27.064246.

38. Khawaldeh, S. et al. Subthalamic nucleus activity dynamics and limb movement prediction in Parkinson's disease. Brain 143, 582-596 (2020).

39. Lofredi, R. et al. Beta bursts during continuous movements accompany the velocity decrement in Parkinson's disease patients. Neurobiology of Disease (2019) doi:10.1016/j.nbd.2019.03.013.

40. Little, S., Bonaiuto, J., Barnes, G. \& Bestmann, S. Human motor cortical beta bursts relate to movement planning and response errors. PLoS Biol 17, e3000479 (2019).

41. Tinkhauser, G. et al. Beta burst coupling across the motor circuit in Parkinson's disease. Neurobiology of Disease 117, 217-225 (2018).

42. Tinkhauser, G. et al. Beta burst dynamics in Parkinson's disease OFF and ON dopaminergic medication. Brain 140, 2968-2981 (2017).

43. Boon, L. I. et al. A systematic review of MEG-based studies in Parkinson's disease: The motor system and beyond. Hum Brain Mapp 40, 2827-2848 (2019). 
medRxiv preprint doi: https://doi.org/10.1101/2021.06.27.21259592; this version posted June 30, 2021. The copyright holder for this preprint (which was not certified by peer review) is the author/funder, who has granted medRxiv a license to display the preprint in perpetuity.

It is made available under a CC-BY 4.0 International license .

572

573

574

575

576

577

578

579

580

581

582

583

584

585

586

587

588

589

590

591

592

593

594

44. Salmelin, R., Hämäläinen, M., Kajola, M. \& Hari, R. Functional Segregation of Movement-Related Rhythmic Activity in the Human Brain. Neurolmage 2, 237-243 (1995).

45. Salmelin, R. \& Hari, R. Spatiotemporal characteristics of sensorimotor neuromagnetic rhythms related to thumb movement. Neuroscience 60, 537-550 (1994).

46. Donoghue, T. et al. Parameterising neural power spectra into periodic and aperiodic components. Nat Neurosci 23, 1655-1665 (2020).

47. He, B. J., Zempel, J. M., Snyder, A. Z. \& Raichle, M. E. The Temporal Structures and Functional Significance of Scale-free Brain Activity. Neuron 66, 353-369 (2010).

48. Bardouille, T., Bailey, L. \& CamCAN Group. Evidence for age-related changes in sensorimotor neuromagnetic responses during cued button pressing in a large open-access dataset. Neurolmage 193, 25-34 (2019).

49. Wolpe, N. et al. Ageing increases reliance on sensorimotor prediction through structural and functional differences in frontostriatal circuits. Nature Communications 7, (2016).

50. Yau, Y. et al. Network connectivity determines cortical thinning in early Parkinson's disease progression. Nat Commun 9, 12 (2018).

51. Zich, C., Quinn, A. J., Mardell, L. C., Ward, N. S. \& Bestmann, S. Dissecting Transient Burst Events. Trends in Cognitive Sciences S136466132030173X (2020) doi:10.1016/j.tics.2020.07.004.

52. Muralidharan, V. \& Aron, A. R. Behavioral Induction of a High Beta State in Sensorimotor Cortex Leads to Movement Slowing. Journal of Cognitive Neuroscience 1-18 (2021) doi:10.1162/jocn_a_01717.

53. Vinding, M. C. et al. Attenuated beta rebound to proprioceptive afferent feedback in Parkinson's disease. Scientific Reports 9, (2019).

54. De Pablo-Fernández, E., Lees, A. J., Holton, J. L. \& Warner, T. T. Prognosis and Neuropathologic Correlation of Clinical Subtypes of Parkinson Disease. JAMA Neurol 76, 470 (2019). 
medRxiv preprint doi: https://doi.org/10.1101/2021.06.27.21259592; this version posted June 30, 2021. The copyright holder for this preprint (which was not certified by peer review) is the author/funder, who has granted medRxiv a license to display the preprint in perpetuity.

It is made available under a CC-BY 4.0 International license .

595

596

597

598

599

600

601

602

603

604

605

606

607

608

609

610

611

612

613

614

615

616

617

55. Göttgens, I. et al. The Impact of Sex and Gender on the Multidisciplinary Management of Care for Persons With Parkinson's Disease. Frontiers in Neurology 11, (2020).

56. Elbaz, A. et al. Risk tables for parkinsonism and Parkinson's disease. Journal of Clinical Epidemiology 55, 25-31 (2002).

57. Georgiev, D., Hamberg, K., Hariz, M., Forsgren, L. \& Hariz, G.-M. Gender differences in Parkinson's disease: A clinical perspective. Acta Neurol Scand 136, 570-584 (2017).

58. Gillies, G. E., Pienaar, I. S., Vohra, S. \& Qamhawi, Z. Sex differences in Parkinson's disease. Frontiers in Neuroendocrinology 35, 370-384 (2014).

59. Cook, A. J., Pfeifer, K. J. \& Tass, P. A. A Single Case Feasibility Study of Sensorimotor Rhythm Neurofeedback in Parkinson's Disease. Front. Neurosci. 15, 623317 (2021).

60. Hoehn, M. M. \& Yahr, M. D. Parkinsonism: onset, progression, and mortality. Neurology 17, 427-427 (1967).

61. American Psychiatric Association. Diagnostic and Statistical Manual of Mental Disorders. (American Psychiatric Publishing, 2013).

62. Tomlinson, C. L. et al. Systematic review of levodopa dose equivalency reporting in Parkinson's disease. Movement Disorders (2010) doi:10.1002/mds.23429.

63. Goetz, C. G. et al. Movement disorder society-sponsored revision of the unified Parkinson's disease rating scale (MDS-UPDRS): Process, format, and clinimetric testing plan. Movement Disorders (2007) doi:10.1002/mds.21198.

64. Nasreddine, Z. S. et al. The Montreal Cognitive Assessment, MoCA: a brief screening tool for mild cognitive impairment. Journal of the American Geriatrics Society 53, 695-699 (2005).

65. Fischl, B. et al. Sequence-independent segmentation of magnetic resonance images. Neurolmage 23, S69S84 (2004). 
medRxiv preprint doi: https://doi.org/10.1101/2021.06.27.21259592; this version posted June 30, 2021. The copyright holder for this preprint (which was not certified by peer review) is the author/funder, who has granted medRxiv a license to display the preprint in perpetuity.

It is made available under a CC-BY 4.0 International license .

66. Dale, A. M., Fischl, B. \& Sereno, M. I. Cortical Surface-Based Analysis: I. segmentation and surface reconstruction. Neurolmage 9, 179-194 (1999).

67. Destrieux, C., Fischl, B., Dale, A. \& Halgren, E. Automatic parcellation of human cortical gyri and sulci using standard anatomical nomenclature. Neurolmage 53, 1-15 (2010).

68. Fischl, B. \& Dale, A. M. Measuring the thickness of the human cerebral cortex from magnetic resonance images. Proceedings of the National Academy of Sciences 97, 11050-11055 (2000).

69. Taulu, S. \& Simola, J. Spatiotemporal signal space separation method for rejecting nearby interference in MEG measurements. Physics in Medicine and Biology 51, 1759-1768 (2006).

70. Gramfort, A. et al. MEG and EEG data analysis with MNE-Python. Frontiers in Neuroscience 7, 267 (2013).

71. Hyvarinen, A. Fast and robust fixed-point algorithms for independent component analysis. IEEE Transactions on Neural Networks 10, 626-634 (1999).

72. Dale, A. M. et al. Dynamic Statistical Parametric Mapping: Combining fMRI and MEG for High-Resolution Imaging of Cortical Activity. Neuron 26, 55-67 (2000).

73. Oostenveld, R., Fries, P., Maris, E. \& Schoffelen, J.-M. FieldTrip: Open Source Software for Advanced Analysis of MEG, EEG, and Invasive Electrophysiological Data. Computational Intelligence and Neuroscience 2011, 1-9 (2011).

74. R Core Team. R: A Language and Environment for Statistical Computing. (R Foundation for Statistical Computing, 2020).

75. Goetz, C. G. et al. Movement Disorder Society-sponsored revision of the Unified Parkinson's Disease Rating Scale (MDS-UPDRS): Scale presentation and clinimetric testing results. Movement Disorders 23, 2129-2170 (2008). 
medRxiv preprint doi: https://doi.org/10.1101/2021.06.27.21259592; this version posted June 30, 2021. The copyright holder for this preprint (which was not certified by peer review) is the author/funder, who has granted medRxiv a license to display the preprint in perpetuity.

It is made available under a CC-BY 4.0 International license .

$1 \quad$ Figure and table legends

$2 \quad$ Figrue 1

3 Overview of the data processing pipeline from three minutes raw resting-state MEG, through source

4 reconstruction and extracting the activity in the sensorimotor cortex. To compare features, we did a Fourier

5 transformation of the signal to calculate the PSD and quantified sensorimotor bursts in the time series in the

6 sensorimotor ROI.

$7 \quad$ Figrue 2

8 Grand average PSD (mean+se) for the PD group (blue) and healthy control group (red).

$9 \quad$ Figrue 3

10 Scatterplots of the individual measures and model predictions over age for (A) PSD beta power, (B) burst rate, 11 and (C) PSD broadband 1/f exponent, split between PD patients (blue) and healthy controls (red), and female 12 (solid) and male (dashed). 
medRxiv preprint doi: https://doi.org/10.1101/2021.06.27.21259592; this version posted June 30, 2021. The copyright holder for this preprint (which was not certified by peer review) is the author/funder, who has granted medRxiv a license to display the preprint in perpetuity.

It is made available under a CC-BY 4.0 International license .

\section{Tables}

2 Table 1

3 Group-level summary of the participants included in the analysis. Mean (standard deviation).

\begin{tabular}{|l|l|l|l|}
\hline Measure & Parkinson's patients & Healthy controls & Statistics \\
\hline$N$ & 78 & 60 & \\
\hline Sex (female/male) & $29 / 49$ & $27 / 33$ & $\chi^{2}=0.57, \mathrm{p}=0.45$ \\
\hline Age & $65.6(9.5)$ & $63.93(8.4)$ & Welsh $\mathrm{t}(138.0)=1.08, \mathrm{p}=0.28$ \\
\hline Disease duration & $4.4(3.7)$ years & - & - \\
\hline LEDD & $548(273) \mathrm{mg}$ & - & - \\
\hline MDS-UPDRS-III & $18.9(10.8)$ & - & - \\
\hline MoCA & $26.1(2.8)$ & $26.2(2.1)$ & Welsh $\mathrm{t}(136)=0.10, \mathrm{p}=0.92$ \\
\hline
\end{tabular}

4 Table 2

5 Table 2: Explanation of the main outcome variables in the analysis 
medRxiv preprint doi: https://doi.org/10.1101/2021.06.27.21259592; this version posted June 30, 2021. The copyright holder for this preprint (which was not certified by peer review) is the author/funder, who has granted medRxiv a license to display the preprint in perpetuity.

It is made available under a CC-BY 4.0 International license .

\begin{tabular}{|c|c|c|}
\hline $\begin{array}{l}\text { Variable } \\
\text { Category }\end{array}$ & Variable & Explanation \\
\hline \multirow{8}{*}{ PSD } & Beta power & $\begin{array}{l}\text { The maximum peak in the } 13-30 \mathrm{~Hz} \text { band. Estimated as the height of the Gaussian } \\
\text { function fitted to the PSD after regressing out the } 1 / \mathrm{f} \text { regression line. }\end{array}$ \\
\hline & Beta centre & The dominant frequency bin in the $13-30 \mathrm{~Hz}$ band. Estimated as the mean of the \\
\hline & frequency $(\mathrm{Hz})$ & Gaussian function fitted to the PSD after regressing out the $1 / \mathrm{f}$ regression line \\
\hline & Alpha power & $\begin{array}{l}\text { The maximum peak in the } 8-12 \mathrm{~Hz} \text { band. Estimated as the height of the Gaussian } \\
\text { function fitted to the PSD after regressing out the } 1 / \mathrm{f} \text { regression line. }\end{array}$ \\
\hline & Alpha centre & The dominant frequency bin in the $8-12 \mathrm{~Hz}$ band. Estimated as the mean of the \\
\hline & frequency $(\mathrm{Hz})$ & Gaussian function fitted to the PSD after regressing out the $1 / \mathrm{f}$ regression line. \\
\hline & 1/f intercept & $\begin{array}{l}\text { The intercept of the log-linear regression estimated from the full PSD in the 0.5-40 } \\
\mathrm{Hz} \text { range. }\end{array}$ \\
\hline & 1/f exponent & $\begin{array}{l}\text { The exponent of the log-linear regression-corresponding to the slope of the log- } \\
\text { log transformed PSD-estimated from the full PSD in the } 0.5-40 \mathrm{~Hz} \text { range }\end{array}$ \\
\hline \multirow{4}{*}{ Bursts } & Rate & $\begin{array}{l}\text { The number of burst events in the sensorimotor time series divided by the length } \\
\text { of time series. }\end{array}$ \\
\hline & Duration (ms) & $\begin{array}{l}\text { Duration of the burst events defined as the time the time-series is above threshold } \\
\text { until the next time-point it drops below the threshold. }\end{array}$ \\
\hline & Interval (ms) & $\begin{array}{l}\text { Time from the mu/beta time-series drops below threshold until the next time- } \\
\text { point it reaches threshold again. }\end{array}$ \\
\hline & Amplitude & The maximum amplitude of the mu/beta time-series within one burst event. \\
\hline
\end{tabular}

7 Table 3

8 Regression coefficients and $95 \% \mathrm{Cl}$ for the regression models of the sensorimotor signal features (Table 2) with

9 Group, Age, Sex, and Cortical Thickness. Values in red indicate coefficients of statistically significant factors in

10 the model comparison. LL: lower limit, UL: upper limit. 
medRxiv preprint doi: https://doi.org/10.1101/2021.06.27.21259592; this version posted June 30, 2021. The copyright holder for this preprint (which was not certified by peer review) is the author/funder, who has granted medRxiv a license to display the preprint in perpetuity.

It is made available under a CC-BY 4.0 International license.

\begin{tabular}{|c|c|c|c|c|c|c|c|}
\hline $\begin{array}{l}\text { Variable } \\
\text { category }\end{array}$ & Variable & $\begin{array}{l}\text { Midline } \\
\text { function }\end{array}$ & Rest tremor & Rigidity & $\begin{array}{l}\text { Bradykinesia } \\
\text { upper } \\
\text { extremity }\end{array}$ & $\begin{array}{l}\text { Postural and } \\
\text { kinetic } \\
\text { tremors }\end{array}$ & $\begin{array}{l}\text { Bradykinesia } \\
\text { lower limb }\end{array}$ \\
\hline & Intercept & -0.42 & -0.52 & -0.33 & 0.02 & -0.26 & 0.12 \\
\hline & & LL: -0.80 & LL: -0.93 & LL: -0.80 & LL: -0.40 & LL: -0.71 & LL: -0.71 \\
\hline & & UL: -0.04 & UL: -0.13 & UL: 0.13 & UL: 0.40 & UL: 0.16 & UL: 0.19 \\
\hline \multirow{18}{*}{ PSD } & Beta power & 0.33 & 0.24 & 0.33 & -0.18 & 0.00 & -0.22 \\
\hline & & LL: -0.06 & LL: -0.16 & LL: -0.12 & LL: -0.57 & LL: -0.41 & LL: -0.43 \\
\hline & & UL: 0.70 & UL: 0.64 & UL: 0.78 & UL: 0.17 & UL: 0.42 & UL: 0.44 \\
\hline & Beta centre & 0.02 & -0.20 & 0.03 & -0.11 & -0.13 & 0.01 \\
\hline & frequency & LL: -0.27 & LL: -0.50 & LL: -0.32 & LL: -0.38 & LL: -0.46 & LL: -0.45 \\
\hline & & UL: 0.30 & UL: 0.10 & UL: 0.36 & UL: 0.20 & UL: 0.20 & UL: 0.19 \\
\hline & Alpha & -0.11 & -0.22 & -0.12 & 0.24 & 0.11 & 0.02 \\
\hline & power & LL: -0.50 & LL: -0.61 & LL: -0.58 & LL: -0.14 & LL: -0.34 & LL: -0.34 \\
\hline & & UL: 0.28 & UL: 0.21 & UL: 0.35 & UL: 0.66 & UL: 0.57 & UL: 0.54 \\
\hline & Alpha & 0.01 & 0.13 & 0.12 & 0.29 & 0.08 & 0.22 \\
\hline & centre & LL: -0.24 & LL: -0.16 & LL: -0.16 & LL: 0.01 & LL: -0.21 & LL: -0.22 \\
\hline & frequency & UL: 0.24 & UL: 0.40 & UL: 0.43 & UL: 0.56 & UL: 0.38 & UL: 0.38 \\
\hline & $1 / f$ & -0.13 & 0.47 & 0.45 & -0.59 & 0.35 & -0.98 \\
\hline & intercept & LL: -1.11 & LL: -0.66 & LL: -0.86 & LL: -1.63 & LL: -0.84 & LL: -0.89 \\
\hline & & UL: 0.89 & UL: 1.54 & UL: 1.70 & UL: 0.42 & UL: 1.51 & UL: 1.50 \\
\hline & $1 / f$ & -0.05 & -0.26 & -0.16 & 0.17 & -0.02 & 0.46 \\
\hline & exponent & LL: -0.67 & LL: -0.87 & LL: -0.86 & LL: -0.47 & LL: -0.74 & LL: -0.73 \\
\hline & & UL: 0.56 & UL: 0.39 & UL: 0.63 & UL: 0.81 & UL: 0.70 & UL: 0.68 \\
\hline \multirow{12}{*}{ Burst } & Rate & 0.13 & 0.05 & 0.06 & -0.60 & -0.08 & 0.15 \\
\hline & & LL: -0.28 & LL: -0.40 & LL: -0.48 & LL: -1.01 & LL: -0.59 & LL: -0.57 \\
\hline & & UL: 0.56 & UL: 0.53 & UL: 0.61 & UL: -0.17 & UL: 0.43 & UL: 0.40 \\
\hline & Length & 0.31 & -0.15 & 0.07 & 0.09 & -0.07 & 0.27 \\
\hline & & LL: 0.00 & LL: -0.46 & LL: -0.32 & LL: -0.22 & LL: -0.42 & LL: -0.42 \\
\hline & & UL: 0.60 & UL: 0.16 & UL: 0.45 & UL: 0.42 & UL: 0.29 & UL: 0.29 \\
\hline & Interval & 0.29 & 0.12 & 0.18 & -0.21 & -0.01 & 0.35 \\
\hline & & LL: -0.07 & LL: -0.31 & LL: -0.31 & LL: -0.58 & LL: -0.44 & LL: -0.46 \\
\hline & & UL: 0.66 & UL: 0.55 & UL: 0.64 & UL: 0.20 & UL: 0.43 & UL: 0.44 \\
\hline & Amplitude & 0.04 & -0.19 & -0.30 & 0.67 & -0.15 & 0.64 \\
\hline & & LL: -0.83 & LL: -1.12 & LL: -1.34 & LL: -0.20 & LL: -1.10 & LL: -1.19 \\
\hline & & UL: 0.88 & UL: 0.72 & UL: 0.78 & UL: 1.59 & UL: 0.88 & UL: 0.84 \\
\hline \multirow{11}{*}{ Other } & Age & 0.03 & 0.00 & 0.00 & 0.01 & 0.01 & 0.01 \\
\hline & & LL: 0.01 & LL: -0.03 & LL: -0.03 & LL: -0.02 & LL: -0.02 & LL: -0.02 \\
\hline & & UL: 0.06 & UL: 0.03 & UL: 0.03 & UL: 0.04 & UL: 0.04 & UL: 0.04 \\
\hline & Sex & 0.70 & 0.74 & 0.55 & -0.14 & 0.33 & -0.25 \\
\hline & & LL: 0.17 & LL: 0.17 & LL: -0.04 & LL: -0.70 & LL: -0.31 & LL: -0.31 \\
\hline & & UL: 1.18 & UL: 1.32 & UL: 1.22 & UL: 0.45 & UL: 0.97 & UL: 0.94 \\
\hline & Cortical & -0.17 & -0.05 & -0.05 & -0.27 & -0.18 & -0.10 \\
\hline & thickness & LL: -0.41 & LL: -0.29 & LL: -0.34 & LL: -0.51 & LL: -0.48 & LL: -0.46 \\
\hline & & UL: 0.07 & UL: 0.22 & UL: 0.25 & UL: -0.03 & UL: 0.11 & UL: 0.11 \\
\hline & Multiple R- & & & & & & \\
\hline & squared & 0.441 & 0.277 & 0.156 & 0.375 & 0.193 & 0.173 \\
\hline
\end{tabular}


medRxiv preprint doi: https://doi.org/10.1101/2021.06.27.21259592; this version posted June 30, 2021. The copyright holder for this preprint (which was not certified by peer review) is the author/funder, who has granted medRxiv a license to display the preprint in perpetuity.

It is made available under a CC-BY 4.0 International license .

12 Table 4

13 Standardised regression coefficients $(95 \% \mathrm{Cl})$ for the six regression models on motor symptoms measured with

14 the MDS-UPDRS-III. Values in bold indicate significant factors in the model comparison. 
medRxiv preprint doi: https://doi.org/10.1101/2021.06.27.21259592; this version posted June 30, 2021. The copyright holder for this preprint (which was not certified by peer review) is the author/funder, who has granted medRxiv a license to display the preprint in perpetuity.

It is made available under a CC-BY 4.0 International license.

\begin{tabular}{|c|c|c|c|c|c|c|c|}
\hline $\begin{array}{l}\text { Variable } \\
\text { category }\end{array}$ & Variable & $\begin{array}{l}\text { Midline } \\
\text { function }\end{array}$ & Rest tremor & Rigidity & $\begin{array}{l}\text { Bradykinesia } \\
\text { upper } \\
\text { extremity }\end{array}$ & $\begin{array}{l}\text { Postural and } \\
\text { kinetic } \\
\text { tremors }\end{array}$ & $\begin{array}{l}\text { Bradykinesia } \\
\text { lower limb }\end{array}$ \\
\hline & Intercept & -0.42 & -0.52 & -0.33 & 0.02 & -0.26 & 0.12 \\
\hline & & LL: -0.80 & LL: -0.93 & LL: -0.80 & LL: -0.40 & LL: -0.71 & LL: -0.71 \\
\hline & & UL: -0.04 & UL: -0.13 & UL: 0.13 & UL: 0.40 & UL: 0.16 & UL: 0.19 \\
\hline \multirow{18}{*}{ PSD } & Beta power & 0.33 & 0.24 & 0.33 & -0.18 & 0.00 & -0.22 \\
\hline & & LL: -0.06 & LL: -0.16 & LL: -0.12 & LL: -0.57 & LL: -0.41 & LL: -0.43 \\
\hline & & UL: 0.70 & UL: 0.64 & UL: 0.78 & UL: 0.17 & UL: 0.42 & UL: 0.44 \\
\hline & Beta centre & 0.02 & -0.20 & 0.03 & -0.11 & -0.13 & 0.01 \\
\hline & frequency & LL: -0.27 & LL: -0.50 & LL: -0.32 & LL: -0.38 & LL: -0.46 & LL: -0.45 \\
\hline & & UL: 0.30 & UL: 0.10 & UL: 0.36 & UL: 0.20 & UL: 0.20 & UL: 0.19 \\
\hline & Alpha & -0.11 & -0.22 & -0.12 & 0.24 & 0.11 & 0.02 \\
\hline & power & LL: -0.50 & LL: -0.61 & LL: -0.58 & LL: -0.14 & LL: -0.34 & LL: -0.34 \\
\hline & & UL: 0.28 & UL: 0.21 & UL: 0.35 & UL: 0.66 & UL: 0.57 & UL: 0.54 \\
\hline & Alpha & 0.01 & 0.13 & 0.12 & 0.29 & 0.08 & 0.22 \\
\hline & centre & LL: -0.24 & LL: -0.16 & LL: -0.16 & LL: 0.01 & LL: -0.21 & LL: -0.22 \\
\hline & frequency & UL: 0.24 & UL: 0.40 & UL: 0.43 & UL: 0.56 & UL: 0.38 & UL: 0.38 \\
\hline & $1 / f$ & -0.13 & 0.47 & 0.45 & -0.59 & 0.35 & -0.98 \\
\hline & intercept & LL: -1.11 & LL: -0.66 & LL: -0.86 & LL: -1.63 & LL: -0.84 & LL: -0.89 \\
\hline & & UL: 0.89 & UL: 1.54 & UL: 1.70 & UL: 0.42 & UL: 1.51 & UL: 1.50 \\
\hline & $1 / f$ & -0.05 & -0.26 & -0.16 & 0.17 & -0.02 & 0.46 \\
\hline & exponent & LL: -0.67 & LL: -0.87 & LL: -0.86 & LL: -0.47 & LL: -0.74 & LL: -0.73 \\
\hline & & UL: 0.56 & UL: 0.39 & UL: 0.63 & UL: 0.81 & UL: 0.70 & UL: 0.68 \\
\hline \multirow{12}{*}{ Burst } & Rate & 0.13 & 0.05 & 0.06 & -0.60 & -0.08 & 0.15 \\
\hline & & LL: -0.28 & LL: -0.40 & LL: -0.48 & LL: -1.01 & LL: -0.59 & LL: -0.57 \\
\hline & & UL: 0.56 & UL: 0.53 & UL: 0.61 & UL: -0.17 & UL: 0.43 & UL: 0.40 \\
\hline & Length & 0.31 & -0.15 & 0.07 & 0.09 & -0.07 & 0.27 \\
\hline & & LL: 0.00 & LL: -0.46 & LL: -0.32 & LL: -0.22 & LL: -0.42 & LL: -0.42 \\
\hline & & UL: 0.60 & UL: 0.16 & UL: 0.45 & UL: 0.42 & UL: 0.29 & UL: 0.29 \\
\hline & Interval & 0.29 & 0.12 & 0.18 & -0.21 & -0.01 & 0.35 \\
\hline & & LL: -0.07 & LL: -0.31 & LL: -0.31 & LL: -0.58 & LL: -0.44 & LL: -0.46 \\
\hline & & UL: 0.66 & UL: 0.55 & UL: 0.64 & UL: 0.20 & UL: 0.43 & UL: 0.44 \\
\hline & Amplitude & 0.04 & -0.19 & -0.30 & 0.67 & -0.15 & 0.64 \\
\hline & & LL: -0.83 & LL: -1.12 & LL: -1.34 & LL: -0.20 & LL: -1.10 & LL: -1.19 \\
\hline & & UL: 0.88 & UL: 0.72 & UL: 0.78 & UL: 1.59 & UL: 0.88 & UL: 0.84 \\
\hline \multirow{11}{*}{ Other } & Age & 0.03 & 0.00 & 0.00 & 0.01 & 0.01 & 0.01 \\
\hline & & LL: 0.01 & LL: -0.03 & LL: -0.03 & LL: -0.02 & LL: -0.02 & LL: -0.02 \\
\hline & & UL: 0.06 & UL: 0.03 & UL: 0.03 & UL: 0.04 & UL: 0.04 & UL: 0.04 \\
\hline & Sex & 0.70 & 0.74 & 0.55 & -0.14 & 0.33 & -0.25 \\
\hline & & LL: 0.17 & LL: 0.17 & LL: -0.04 & LL: -0.70 & LL: -0.31 & LL: -0.31 \\
\hline & & UL: 1.18 & UL: 1.32 & UL: 1.22 & UL: 0.45 & UL: 0.97 & UL: 0.94 \\
\hline & Cortical & -0.17 & -0.05 & -0.05 & -0.27 & -0.18 & -0.10 \\
\hline & thickness & LL: -0.41 & LL: -0.29 & LL: -0.34 & LL: -0.51 & LL: -0.48 & LL: -0.46 \\
\hline & & UL: 0.07 & UL: 0.22 & UL: 0.25 & UL: -0.03 & UL: 0.11 & UL: 0.11 \\
\hline & Multiple R- & & & & & & \\
\hline & squared & 0.441 & 0.277 & 0.156 & 0.375 & 0.193 & 0.173 \\
\hline
\end{tabular}


medRxiv preprint doi: https://doi.org/10.1101/2021.06.27.21259592; this version posted June 30, 2021. The copyright holder for this preprint (which was not certified by peer review) is the author/funder, who has granted medRxiv a license to display the preprint in perpetuity.

It is made available under a CC-BY 4.0 International license .

Table 5

Statistically significant correlation coefficients between all main variables. Green colors indicate a positive correlation between variables and red colors indicate a negative correlation between variables. The intensity of the color scales with the correlation coefficient.

Variable category

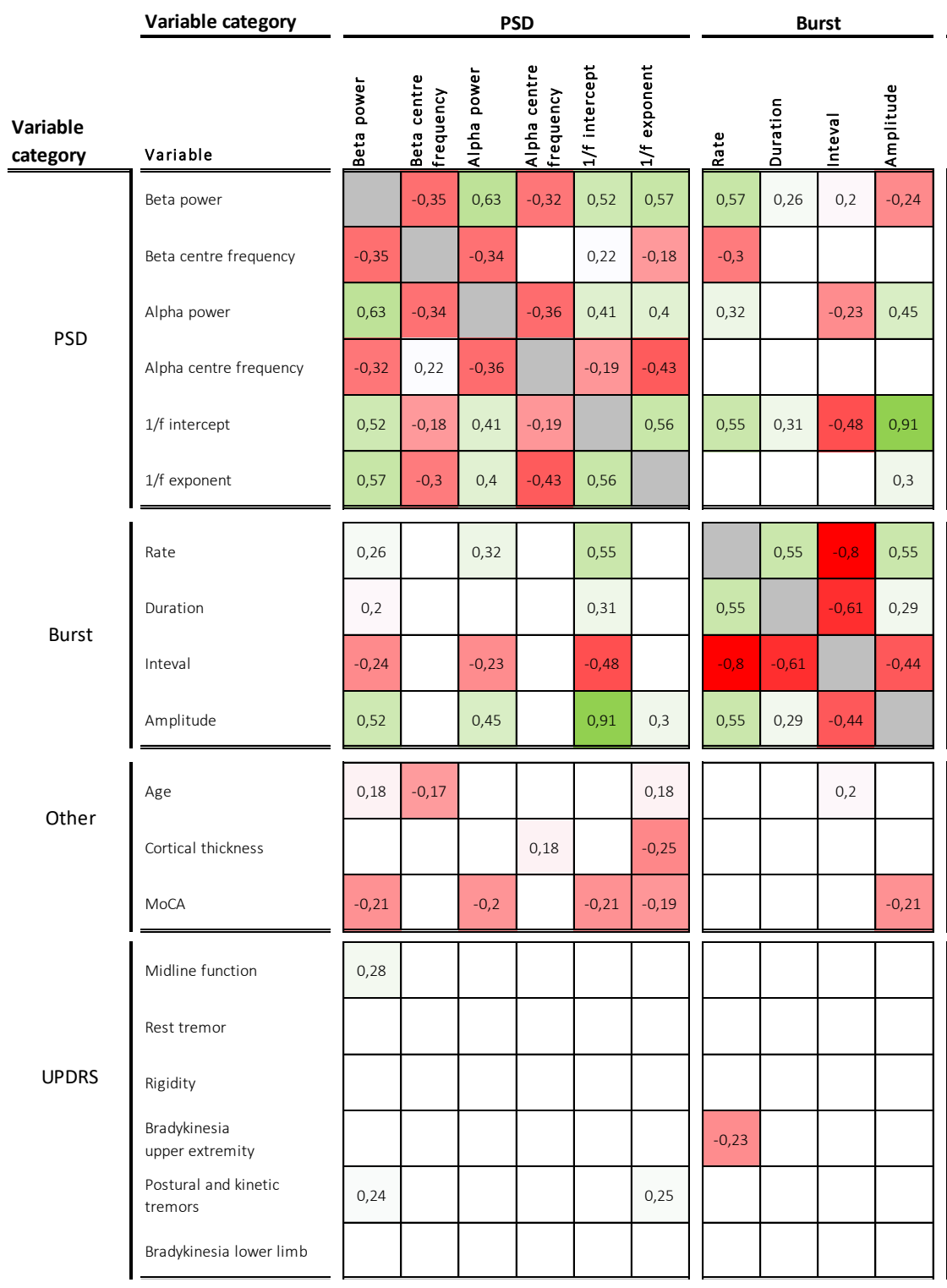

Other
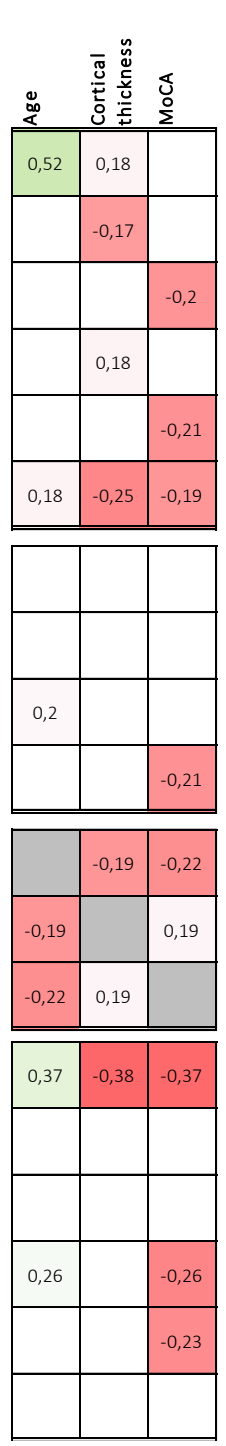

UPDRS
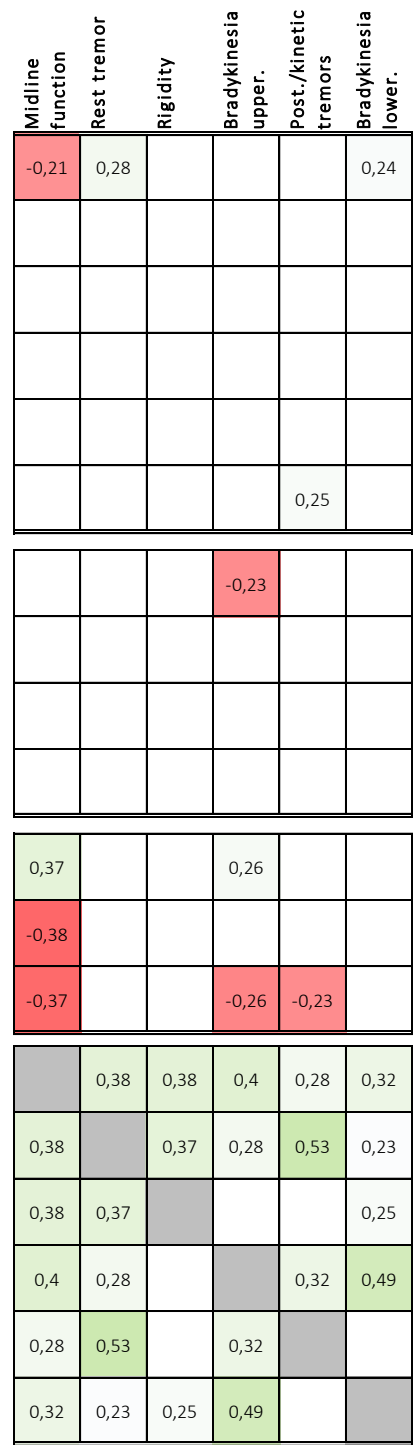